\title{
Numerical simulation of explosive volcanic eruptions from the conduit flow to global atmospheric scales
}

\author{
Christiane Textor $\left({ }^{1}\right)\left({ }^{2}\right)$, Hans-F. Graf $\left({ }^{2}\right)\left({ }^{*}\right)$, Antonella Longo $\left({ }^{3}\right)\left({ }^{4}\right)$, Augusto Neri $\left(^{3}\right)$, \\ Tomaso Esposti Ongaro $\left({ }^{3}\right)$, Paolo Papale $\left({ }^{3}\right)$, Claudia Timmreck $\left({ }^{2}\right)$ and Gerald G.J. Ernst $\left({ }^{5}\right)\left({ }^{* *}\right)$ \\ (') Laboratoire des Sciences du Climat et de l'Environnement, CEA-CNRS, Gif-sur-Yvette, France \\ (') Max-Planck-Institut für Meteorologie, Hamburg, Germany \\ (3) Istituto Nazionale di Geofisica e Vulcanologia, Sede di Pisa, Italy \\ $\left.{ }^{4}\right)$ Dipartimento di Scienze della Terra, Università degli Studi di Pisa, Italy \\ $\left(^{5}\right)$ Centre for Environmental and Geophysical Flows, Department of Earth Sciences, University of Bristol, U.K.
}

\begin{abstract}
Volcanic eruptions are unsteady multiphase phenomena, which encompass many inter-related processes across the whole range of scales from molecular and microscopic to macroscopic, synoptic and global. We provide an overview of recent advances in numerical modelling of volcanic effects, from conduit and eruption column processes to those on the Earth's climate. Conduit flow models examine ascent dynamics and multiphase processes like fragmentation, chemical reactions and mass transfer below the Earth surface. Other models simulate atmospheric dispersal of the erupted gas-particle mixture, focusing on rapid processes occurring in the jet, the lower convective regions, and pyroclastic density currents. The ascending eruption column and intrusive gravity current generated by it, as well as sedimentation and ash dispersal from those flows in the immediate environment of the volcano are examined with modular and generic models. These apply simplifications to the equations describing the system depending on the specific focus of scrutiny. The atmospheric dispersion of volcanic clouds is simulated by ash tracking models. These are inadequate for the first hours of spreading in many cases but focus on long-range prediction of ash location to prevent hazardous aircraft - ash encounters. The climate impact is investigated with global models. All processes and effects of explosive eruptions cannot be simulated by a single model, due to the complexity and hugely contrasting spatial and temporal scales involved. There is now the opportunity to establish a closer integration between different models and to develop the first comprehensive description of explosive eruptions and of their effects on the ground, in the atmosphere, and on the global climate.
\end{abstract}

Key words numerical modeling - explosive volcanic eruptions - conduit flow - multiphase flow simulation - stratospheric sulfate aerosol

Mailing address: Dr. Christiane Textor, Laboratoire des Sciences du Climat et de l'Environnement, CEA-CNRS L'Orme des Merisiers, F-91191 Gif-sur-Yvette Cedex, France; e-mail: christiane.textor@gmx.de

$\left(^{*}\right)$ Now at: Centre for Atmospheric Science, Department Geography, University of Cambridge, Downing Place, Cambridge CB2 3EN, U.K.

$\left(^{* *}\right)$ Now at: Mercator and Ortelius Research Centre for Eruption Dynamics, Department of Geology and Soil Science, University of Ghent, Krijgslaan 281, S8, 9000 Gent, Belgium.

\section{Introduction and review of basic concepts}

Explosive eruptions are among the most fascinating and complex natural phenomena. At their initiation stage, gas-rich viscous magma experiences a pressure drop (a little as in the uncorking of a champagne bottle but where the liquid would be $10^{4}$ to $10^{12}$ times more viscous, and over-pressure is tens of bars). The exsolution of dissolved gases (mostly water and $\mathrm{CO}_{2}$ ), their thousand-fold expansion and acceleration toward the surface occur in succession. 
During an explosive eruption, an over-pressured magmatic foam is generated and fragments in the conduit (e.g., Carroll and Holloway, 1994; Gilbert and Sparks, 1998). The resulting fragmented medium accelerates upward generating a multiphase, over-pressured and upward-directed, negatively buoyant, momentumdominated jet. Multiphase flows exiting conduits are modelled to be 5-300 times denser than surrounding air. Decompression to atmospheric pressure, vigorous entrainment, rapid heat exchange from pyroclasts (about $90 \%$ and $60 \%$ of them are typically less than $1 \mathrm{~mm}$ and $60 \mu \mathrm{m}$ in size respectively) to the entrained air (on timescale of 1-100 s) and further expansion and lowering of bulk density happen next. This can generate a buoyant eruption column rising up to $10-50 \mathrm{~km}$, from which ash falls out. Columns that remain negatively buoyant when the initial source momentum has been exhausted produce collapsing fountains and pyroclastic density currents, which may also source giant volcanic clouds (e.g., Sparks et al., 1997; Gilbert and Sparks, 1998; Dartevelle et al., 2002).

An eruption column can ascend until the kinetic and thermal energy, plus the latent heat energy release from water vapour condensation, equal the work to be done against the increase in potential energy at a certain height in the atmosphere. Ultimately, the column reaches its height of neutral buoyancy, where its bulk density converges to that of air. At this level, either a radial or a parabolically-shaped current is generated (Carey and Sparks, 1986; Bursik et al., 1992a; Ernst et al., 1994; Rose et al., 2001). Most of the ash responsible for widespread dispersal and hazards is released from the eruption column and advected within gravity currents flows (e.g., Bursik et al., 1992a,b; Sparks et al., 1992; Ernst et al., 1996; Bonadonna et al., 1998). Large particles $(>>1 \mathrm{~cm})$ are ejected along ballistic trajectories, which are decoupled from the fluid motion of the eruption column. Ballistic particles are not discussed here (and typically are not specifically considered by the models) because they contribute only a minor fraction to the total volcanic solid mass. Unlike small-sized ash, which is suspended by flow turbulence and moves with the fluid, ballistic particles are volumetrically very minor in the sort of intense explosive eruptions considered here (see Riedel et al., 2003, for more discussions about ballistic ejection and modelling). The current of volcanic material injected into the stratosphere initially flows laterally under gravity while its leading edge is advected at the local wind speed. The current is then sheared by gradients in both wind direction and speed, diffused by atmospheric turbulence, may be transported and stretched around or in between mesoscale eddies, and is finally dispersed zonally and meridionally by the global circulation within some weeks and months, respectively (see Sparks et al., 1997; Gilbert and Sparks, 1998, for further reviews of physical concepts).

Eruptions can produce hazardously high local atmospheric concentrations of volcanic ash, acidic gases and secondary particles (e.g., Baxter et al., 1999; Horwell et al., 2003a,b). Ash can be widely dispersed and have detrimental effects on people, their activities and the environment (e.g., Lipman and Mullineaux, 1981; Newhall and Punongbayan, 1996; Druitt and Kokelaar, 2002). The dispersal of the volcanic products, including silicate solid particles, gases $\left(\mathrm{H}_{2} \mathrm{O}, \mathrm{CO}_{2}, \mathrm{SO}_{2}\right.$, $\mathrm{H}_{2} \mathrm{~S}, \mathrm{HCl}$, and others) and aerosols condensing from gases in the volcanic clouds can impact upon the environment and human activities. Ash is hazardous as it falls on the ground (e.g., roof collapse hazard) where it accounts for 5\% of direct casualties and for much of the widespread damage from explosive eruptions. Ash is also a hazard in the air where it disrupts international air traffic and airport operations, resulting in substantial loss of revenues for air companies. Since 1980 , there have been well over 100 reported encounters between volcanic clouds and jet airplanes (including very close calls in about 5$10 \%$ of cases). Even minute amounts of volcanic ash far from its source and some days after emissions can substantially damage jet engines (e.g., Casadevall, 1994; Grindle and Burcham, 2002, 2003). That these encounters could not been avoided indicates a need for more accurate, nearreal-time, ash dispersal forecasts that can be communicated more rapidly and effectively (ICAO, 2000). In addition, volcanic activity leads to manifold effects on atmospheric chemistry and climate.

Ash settles within hours to weeks and thus does not directly affect global climate. Gases re- 
main much longer aloft and can be dispersed widely and recurrently in the free troposphere (especially in between eruptions) and in the stratosphere (during less frequent but much larger explosive events). There, sulphur-containing gases (mainly $\mathrm{SO}_{2}$, and $\mathrm{H}_{2} \mathrm{~S}$ ), of special relevance to the atmosphere-climate effects, are oxidatively converted to sulphuric acid, which condenses to form sulphate aerosols on a characteristic timescale of about one to two months in the stratosphere (e.g., Bluth et al., 1993; Read et al., 1993). Stratospheric aerosol residence times are longer, accounting for effects lasting up to a several years before return to background conditions (e.g., WMO, 2003).

Sulphate aerosols alter the Earth's radiation balance (e.g., Stenchikov et al., 1998): they absorb and emit in the near-IR and longwave, causing in situ local heating in the stratosphere and increasing the downward radiative flux, thus resulting in surface warming. Aerosols also backscatter part of the incoming solar radiation leading to surface cooling. The net result is a surface cooling counteracting greenhouse warming for the few years before aerosol loadings return to background levels. The presence of volcanic aerosol in the stratosphere alters the chemistry and dynamics of the stratosphere (e.g., Pitari, 1993; Pitari and Rizzi, 1993). For large equatorial explosive eruptions, there is a dynamic feedback on tropospheric circulation from forcing upon differential stratospheric heating, leading to abnormally warm winters over the Northern Hemisphere continents in the years following the eruption (Groisman, 1992; Robock and Mao, 1992).

Stratospheric volcanic aerosols can be transported vertically across the tropopause (e.g., Ansmann et al., 1996, 1997) and increase the amount and persistence of high-level clouds (Sassen, 1992; Sassen et al., 1995; Lohmann et al., 2003). There is strong evidence that changes in the radiative properties of cirrus clouds can last several years after large explosive eruptions (Minnis et al., 1993).

Stratospheric sulphate aerosols can also serve as sites for heterogeneous reactions, such as those on polar stratospheric clouds, which deplete ozone in the presence of halogens like chlorine or bromine (e.g., Michelangeli et al., 1989; Hofmann and Solomon, 1989; Granier and Brasseur, 1992; Solomon et al., 1996). Ozone depletion could be enhanced through direct stratospheric injection of volcanic halogens (Prather, 1992), although there is still much debate about how much of these gases actually reach the stratosphere (Tabazadeh and Turco, 1993; Textor et al., 2003b,c).

The atmospheric effects of eruptions depend on magma composition (including volatile content and nature), eruption style, and ambient conditions in both the lithosphere and atmosphere. Specific volcanoes are capable of contrasting styles of activity depending upon the stage of maturation reached in the magma chamber and conduit system and upon the physical state of the volcanic edifice. Volcanic emissions undergo modification processes in the conduit and crater (especially in the case of flooded vents or of magmas coming into prolonged contact with aquifers), in the eruption column and during long-range atmospheric transport. There is also a growing understanding that volcanic clouds have a lot more in common with meteorological clouds than previously realized (e.g., Rose et al., 1995; Herzog et al., 1998; Durant and Ernst, 2003; Lacasse et al., 2003; Textor et al., 2005a,b). Prior to 1997-1998, meteorological aspects (with the exception of a consideration of the latent heat effects on cloud rise; e.g., Woods, 1993; Glaze and Baloga, 1996) had been left out of eruption cloud models. Small scale processes within the eruption column have a large - albeit indirect - effect upon the atmosphere and climate. Ash interacts with hydrometeors and forms mixed phase aggregates during ascent and recirculation within the eruption column (e.g., Veitch and Woods, 2001; Textor et al., 2005a,b). Gases condense and freeze on ash, hydrometeors and the aggregates (Tabazadeh and Turco, 1993; Textor et al., 2003b,c). These processes affect residence times, removal rates and the stratospheric injection of gases (i.e., the initial volcanic forcing upon climate). For a recent review on atmospheric effects of volcanic eruptions see Textor et al. (2003a).

Direct observations of conduit processes have not been feasible so far, and key eruptive parameters have not been measured in situ. What we know about the explosive eruption processes occurring below the Earth's surface comes from 
analyses of eruptive products (Marti et al., 1999; Polacci et al., 2001; Klug et al., 2002), and of geophysical signals (Vergniolle and Brandeis, 1994; Ripepe et al., 2001; Chouet, 2003), from laboratory experiments (for references see Gilbert and Sparks, 1998), and from numerical simulations of magma ascent (e.g., Melnik and Sparks, 2002). Liquid and multiphase magma rheology can be estimated in the laboratory for a relevant range of composition, temperature, dissolved volatile contents and strain rates (Dingwell, 1998). This provides a basis for understanding the rheological behaviour of viscoelastic magma, and the constitutive equations for use in numerical simulations of magma flow (Manga et al., 1998; Saar et al., 2001; Llewellin et al., 2002a,b). Fragmentation experiments are now routinely carried out in apparata, where a magma parcel is pressurized at high temperature and then suddenly depressurised and fragmented. The accelerated particles are collected and their textures compared with those of volcanic particles (Martel et al., 2000, 2001; Spieler et al., 2003). Experiments on gas bubble nucleation and growth in liquids undergoing variable rates of pressure decrease document that non-equilibrium effects control the distribution of volatile components in the liquid and gas phases (Navon and Lyakhovsky, 1998).

Similarly, direct measurements of volcanic emissions in the atmosphere are quite rare. However, they can be studied remotely by groundbased, airborne and satellite instruments. Lidars constrain aerosol vertical distributions, but until recently they could only operate during the night under clear sky conditions. Observations of emissions (mostly $\mathrm{SO}_{2}$ ) during small eruptive events and of quasi-permanent emissions are possible with ground-based or airborne remote instruments like COSPEC, FTIR (e.g., Oppenheimer et al., 2002) and DOAS (e.g., Bobrowski et al., 2003) instruments. Direct sampling is accomplished by balloon and research aircrafts, flown through the clouds. There are, however, only sporadic measurements, with no global coverage. Recent developments in satellite remote sensing have expanded the capability to monitor volcanoes from space (e.g., Rose et al., 1995, 2000, 2001, 2003; and Lacasse et al., 2003), but satellite data for $\mathrm{SO}_{2}$ and ash are cur- rently only useful for strong sources (e.g., Bluth et al., 1992). Eleven instruments have been deployed on satellites in the past 30 years. Most are limited time research instruments without operational capacity, $\mathrm{SO}_{2}$ is the only volcanic gas so far monitored operationally by satellite.

Since the 1970s, there have been crucial advances in understanding the basic physics of explosive eruptions, and their effects upon the atmosphere and climate. These are summarized by Sparks et al. (1997) and Gilbert and Sparks (1998), and by McCormick et al. (1995) and Robock (2000), respectively. Since the 1990s, there have also been developments, not yet reviewed, in numerical modelling. Numerical advances can now be harvested to assess the timedependent dynamics and microphysics of eruption clouds and of their impacts.

Here we provide an overview of these recent advances. Section 2 describes conduit flow modelling. Section 3 focuses on numerical simulation of dispersal processes on the mesoscalegamma (2-20 km - some tens of minutes), concentrating on rapid processes in the jet, lower convective regions, and pyroclastic density currents. The terms 'mesoscale alpha, beta, gamma', 'regional', and 'global' originate from the terminology of meteorology. The respective spatial and temporal scales are given in the text. Section 4 concentrates on the mesoscale-beta (20-200 km - some hundreds of minutes) concerning the eruption column. The far-field ash dispersion on the mesoscale-alpha (200-2000 $\mathrm{km}$ - some tens of hours) and the regional scale is illustrated in Section 5. Climate effects of eruptions on the global scale are discussed in Section 6. There is much yet to explore about the physics of source eruption processes, the meteorology and climate effects of volcanic clouds. Multi-scale numerical modelling, and experimentation, together with remote sensing and in situ measurements will play a key role in advancing understanding of these processes.

\section{Conduit flow modelling}

Volcanic conduits connect the deep regions of magma accumulation inside the crust with the Earth's surface. Transit times for magmas 
ascending in conduits and leading to sustained explosive eruptions are typically of the order of minutes, up to $10-20 \mathrm{~min}$. Here the physical and chemical processes are so effective that they produce order of magnitude changes in flow variables, and deeply modify the continuum properties of magma through magma fragmentation and production of gas-particle mixtures.

The modelling of magma ascent dynamics is currently well developed. Typical assumptions include steady, one-dimensional, isothermal, multiphase non-equilibrium flow. This accounts for a relatively large number of factors characterizing real magmas, like their chemical composition (10 major oxides plus 2 major volatile components $\mathrm{H}_{2} \mathrm{O}$ and $\mathrm{CO}_{2}$ ) and solid content (crystals and eroded rock fragments)
(Papale et al., 1998; Papale and Polacci, 1999), to predict the occurrence of fragmentation under dynamic constraints (Papale, 1999a; Melnik, 2000), and to take into account variable amounts of different pyroclast components originated by the fragmentation process $(\mathrm{Pa}-$ pale, 2001). Non-isothermal flow of one-phase (homogeneous) magma has been considered by Buresti and Casarosa (1989) and Mastin and Ghiorso (2000). Transient magma flow is considered by Turcotte et al. (1990), Ramos (1995), and Melnik (2000). Proussevitch and Sahagian (1998) modelled transient conduit flow to investigate the role and dynamics of non-equilibrium nucleation and growth of gas bubbles in silicic magma. A review of pre-1998 work on conduit flow modeling can be found in Papale (1998).

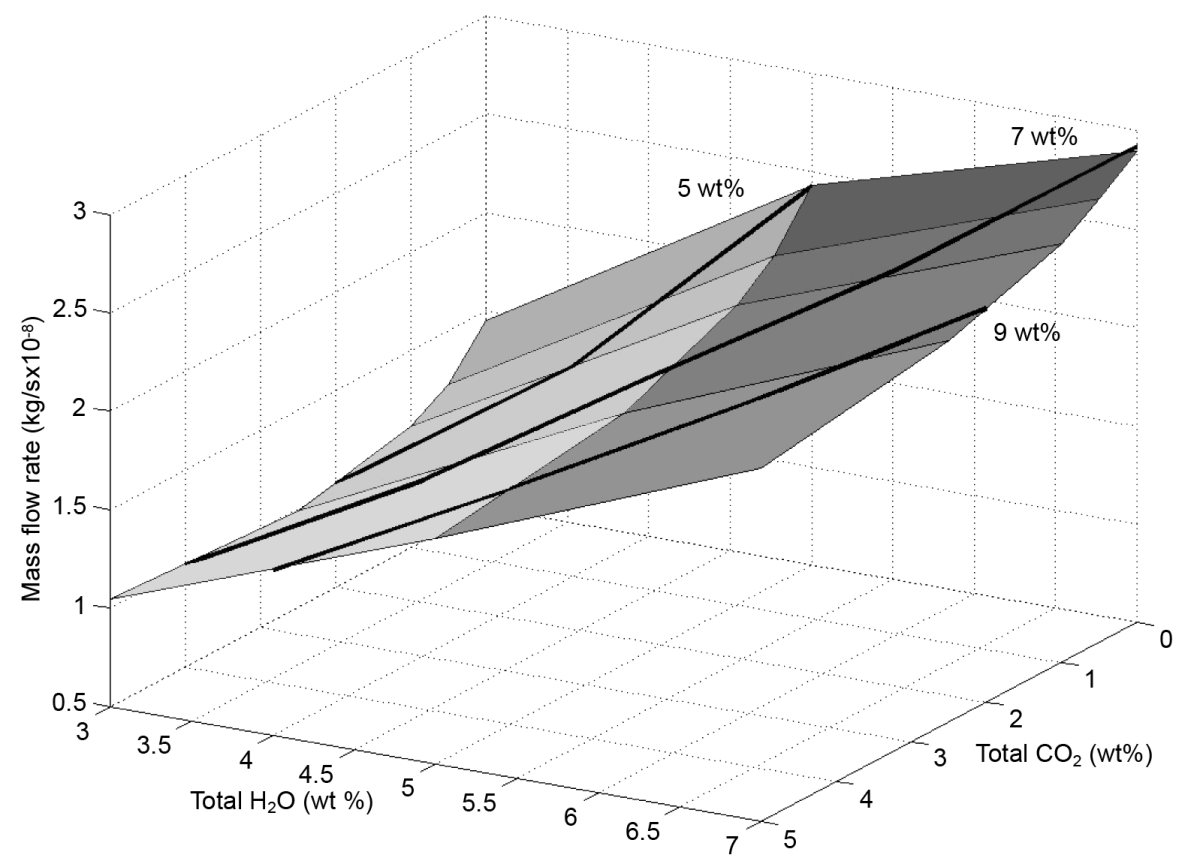

Fig. 1. Mass flow-rate as a function of amount and composition of volatiles $\left(\mathrm{H}_{2} \mathrm{O}\right.$ and $\left.\mathrm{CO}_{2}\right)$ in magma, computed through the model in Papale (2001). The bold lines correspond to cases with equal total volatile content of 5, 7, and $9 \mathrm{wt} \%$, and variable $\mathrm{CO}_{2} / \mathrm{H}_{2} \mathrm{O}$ ratios. Eruptive conditions correspond to rhyolitic magma (composition in Papale and Polacci, 1999) at $1100 \mathrm{~K}$, no crystals in magma, conduit length $7 \mathrm{~km}$, pressure at the chamber top $175 \mathrm{MPa}$, vertical conduit with circular cross-section $100 \mathrm{~m}$ in diameter, unvesicular ash $200 \mu \mathrm{m}$ in diameter formed at fragmentation. 
The use of sets of constitutive equations describing phase properties and interphase as well as phase-wall mechanical interactions has allowed investigation of the relationships between ascent dynamics and the multiphase, multicomponent nature of real magmas. These interactions are strongly non-linear, implying that generalization of numerical results should be avoided. The relatively large number of numerical simulations made to date allows some preliminary conclusions to be drawn. One of them concerns the roles of volatiles in the dynamics of magma ascent. Magmatic volatiles represent the engine of explosive eruptions, since volatile exsolution leads to over-pressure in magma chambers and cracking of chamber walls, thus initiating magma ascent (Tait et al., 1989). It is the combined effect of further exsolution and gas expansion upon depressurisation that leads to magma acceleration, and ultimately to fragmentation and explosive eruption.

Numerical simulations show that different volatiles can have opposing effects on ascent and eruption dynamics. Water is the main volatile component of magmatic gases. Dissolved water reduces magma viscosity, and affects ascent dynamics by increasing the eruption mass flow-rate (Wilson et al., 1980; Papale et al., 1998; Dingwell, 1998). $\mathrm{CO}_{2}$, the second main volatile component in magmas, reduces mass flow-rate, at least up to $\mathrm{CO}_{2}$ mass fractions of $50 \mathrm{wt} \%$ of the total volatile content $(\mathrm{Pa}-$ pale and Polacci, 1999), see fig. 1. These different roles are related to the different solubilities of $\mathrm{H}_{2} \mathrm{O}$ and $\mathrm{CO}_{2}$ in the magma under conduit conditions. $\mathrm{CO}_{2}$ is poorly soluble; thus, its presence causes gas exsolution at much higher pressure than if $\mathrm{H}_{2} \mathrm{O}$ was the only volatile species (Holloway and Blank, 1994; Papale, 1999b). Once a separate gas phase has developed, it carries a fraction of all the volatile components, and thus reduces the amount of $\mathrm{H}_{2} \mathrm{O}$ dissolved in magma. Increasing carbon dioxide can thus both result in more gas available for expansion and acceleration, thus favouring magma flow, as well as in more viscous magma, thus hindering magma flow. Numerical simulations suggest that the latter effect is the dominant one. Hence, knowledge of the true magmatic volatile abundances is needed to simulate erup- tions. Recent modelling of the compositionaldependent saturation surface of multicomponent volatiles in magmas allowed sulphur species to be treated together with water and carbon dioxide (Moretti et al., 2003). New insights will be gained from the simulation of magma ascent by including multicomponent volatile saturation.

Melnik (2000) considered the homogeneous (one-phase) flow of bubbly magma below fragmentation, and the two-phase (separated) flow of gas and particles above fragmentation. The main difference from previous conduit flow models is in the calculated pressure difference between gas and liquid phases. This pressure difference originates from the finite time required for gas bubbles to equilibrate to ambient pressure, and from the high magma viscosity, which acts to increase the equilibration time. Gas-liquid pressure difference over an assigned threshold is also used as the magma fragmentation criterion. The coupling between viscosity, acceleration, and fragmentation leads to a dynamic fragmentation criterion, mathematically similar to that in Papale (1999a), where fragmentation relates to the transition from a viscous to an elastic rheological response of the stressed magma. Thus, fragmentation occurs when the product of viscosity and strain rate exceeds a critical threshold. The threshold that must be exceeded is different in the two models, being dictated by the elastic properties of magma in the viscous to elastic transition model (Dingwell and Webb, 1989; Papale, 1999a), and by the kinetics of gas bubble expansion in the bubble over-pressure model (Melnik, 2000). In the latter case, the threshold is a function of bubble over-pressure and thus also of magma expansion and acceleration. In turn, the gas density and volume fraction are not directly related to pressure as in Papale (1999a), but also depend on the depressurisation rate along the conduit. The result is that multiple regimes of contrasting eruption intensity (or mass flowrate) are possible for one starting set of eruptive conditions (or input data in the simulations). The appearance of such multiple steady-state solutions requires a pressure drop at the base of the conduit (or at the top of the underlying magma chamber) significantly below the volatile 
saturation pressure, and may explain abrupt transitions in eruptive intensity, sometimes inferred from eruption products.

The above studies consider the entire conduit length from the top of a hypothetical magma chamber up to the base of a volcanic crater, above which one-dimensional flow can no longer be assumed. Other investigations for researcher focused on specific aspects of magma flow, without solving the entire flow from the deep homogeneous flow regions below gas exsolution to the shallow gas-pyroclast regions above fragmentation up to the conduit exit. Massol and Jaupart (1999) analysed the crosssectional pre-fragmentation pressure variations in conduits. They documented a decrease in gas pressure from the conduit axis to the walls, implying contrasting depressurisation and degassing histories of distinct magma parcels erupted simultaneously. Costa and Macedonio (2003) analysed the shear-induced viscous dissipation close to the conduit walls, and found that a large temperature increase is expected due to the high viscosities and velocities of magma discharged during explosive eruptions. Their predicted velocity profiles develop a central plug (despite the assumed Newtonian magma rheology) and a region of concentrated shear near the conduit walls. These findings account for the contrasting textures of pumice from some explosive eruptions (Polacci et al., 2001).

Future magma ascent modelling advances may benefit from formulation and solution of a transient, multidimensional, multiphase flow model including the full set of mass, momentum, and energy transport equations, as well as constitutive equations approaching the behaviour of real multiphase multicomponent magmas. Such a model would allow all of the above complex processes to be accounted for in comprehensive numerical simulations of magma ascent dynamics, and in principle it could be employed to describe the dynamics of the entire system from magma chamber to the surface. Coupling with the mechanics of surrounding rocks would allow to take into account both the opening and closing phases of volcanic eruptions, as well as both time-dependent shape variations of magma chamber and conduit walls, and the occurrence of caldera collapse Such a comprehensive model will be the challenge for the researchers focused on subsurface volcanic processes in the next decades.

\section{Numerical simulation of atmospheric dispersal processes by using multiphase flow models on the mesoscale-gamma (2-20 $\mathrm{km}$ - some tens of minutes)}

In the last 20 years significant progress in understanding of pyroclastic dispersal processes was obtained through development of multidimensional, transient and multiphase flow models. These are able to treat the eruptive mixture as a non-homogeneous fluid (Wohletz et al., 1984; Valentine and Wohletz, 1989; Dobran et al., 1993; Neri and Macedonio, 1996; Neri et al., 2003). Such an approach is based on the extension of fundamental transport continuum mechanics equations to a multiphase and multicomponent mixture. According to the multiphase flow theory, the volume occupied by a generic gaseous, solid, or liquid phase cannot be occupied at the same position in time and space by the remaining phases. It is from such a distinction that it is possible to introduce the phase volume fraction as a new dependent variable. A multifield approach is defined, according to which different phases are treated as interpenetrating continua. The high particle mass fraction under typical eruptive conditions justifies the continuum assumption for pyroclasts smaller than about one centimeter (larger particles need to be treated with a Lagrangian approach). The fundamental mass, momentum and energy conservation equations are now solved for each specific phase. This system needs to be closed by constitutive equations expressing the viscous and interphase transport terms as well as the equation of state of the involved phases. The reader is referred to Soo (1967) and Gidaspow (1994) for a complete description of these equations. The system of partial differential equations can be solved numerically, using finite difference or finite element methods, on computational domains extending some tens of kilometres in radial and vertical directions and so far for times of several min- 
utes. The simulation outcome typically consists in the temporal and spatial evolution of several variables - such as concentration, flow field, temperature - for each phase considered.

The application of this type of models allowed description of new and somehow non-intuitive, physical processes occurring during explosive eruptions. Due to the specific characteristics of these models, and their large demand for computing power, they have been mostly applied to the analysis of relatively rapid, localized, and non-equilibrium processes, such as those occurring in the jet, lower convective regions and pyroclastic density currents, herein also named pyroclastic flows sensu lato, generated by gravitational collapse. Processes investigated include the blast dynamics from caldera-forming eruptions (Wohletz et al., 1984), transient motion of ascending eruption columns (Valentine and Wohletz, 1989), interaction between pyroclastic flows and caldera rims (Valentine et al., 1992), the formation of co-ignimbrite clouds (Dobran et al., 1993), propagation of pyroclastic flows as transient waves (Neri and Dobran, 1994), unstable behaviour at the transition between fully convective and fully collapsing regimes (Neri et al., 2002a; Di Muro et al., 2004), and multiparticle dynamics of collapsing volcanic column and pyroclastic flows (Neri et al., 2003).

The models were also used to reconstruct the eruptive dynamics of historic and on-going eruptions. Simulations have been compared to direct or indirect observations whenever available. In more detail, the conduit ascent model described in the previous section (Papale et al., 1998) was used to determine vent boundary conditions for the multiphase flow model (Neri et al., 1998). The linking of two models permitted the reconstruction of the dynamics for the 79 A.D. eruption of Vesuvius. The influence of magmatic properties on the eruptive style of two main phases of the eruption (white and grey pumices) was elucidated (Neri et al. 2002b). Similarly, the multiparticle flow model of Neri et al. (2003) was used to simulate the dynamics of transient short-lived Vulcanian explosions observed at the Soufrière Hills Volcano, Montserrat, West Indies, during AugustOctober 1997 (Clarke et al., 2002). A simplified description of pre-explosive conduit conditions based on observations provided the initial conditions for transient, axi-symmetric, multiphase flow simulations of pyroclastic dispersion. The relationships between the dynamics and the conduit parameters, including volatile content, overpressure, and particle size distribution were examined. Model results illustrated that i) observations of explosions were best reproduced using initial conditions that best matched observationally-constrained input data; ii) vent conditions were highly transient, therefore, models assuming steady vent conditions can not be applied to Vulcanian explosions; iii) decreasing conduit pressure and increasing magmatic water content have similar effects in that they generally increase plume buoyancy, pyroclastic current runout, Dense Rock Equivalent (DRE) ejected and development of ash plumes above pyroclastic currents.

Some of the multiphase flow models were applied to assess pyroclastic flow hazards in high-risk regions, e.g. in the Vesuvian Area, Italy (Dobran et al., 1994; Esposti Ongaro et al., 2002; Todesco et al., 2002). Input data were defined based on knowledge of the magmatic system, its eruptive record, as well as using magma ascent modelling. Figure 2 shows the time wise distribution of the total particle volumetric fraction and gas flow field along the southern flank for a typical sub-Plinian eruption of Vesuvius at three different times after onset of collapse. The three plots illustrate the transient nature of the over-pressured jet and rapid propagation of the flow fed by the pulsating fountain. In this specific case, the flow reaches the Tyrrhenian Sea $7 \mathrm{~km}$ away from the crater in about $6 \mathrm{~min}$. Hot, dilute, fine ash-laden plumes rise above the vent and flows. Important flow variables are quantified, e.g., pyroclastic flow density, temperature, dynamic pressure, etc., that are all crucial in the assessment of the environmental impact.

In all these applications model results appeared to be qualitatively, and in some circumstances quantitatively consistent with observations and, in most cases, able to provide quantitative insights into eruption dynamics that cannot readily be obtained by other means. However, there is still much progress to be made. 

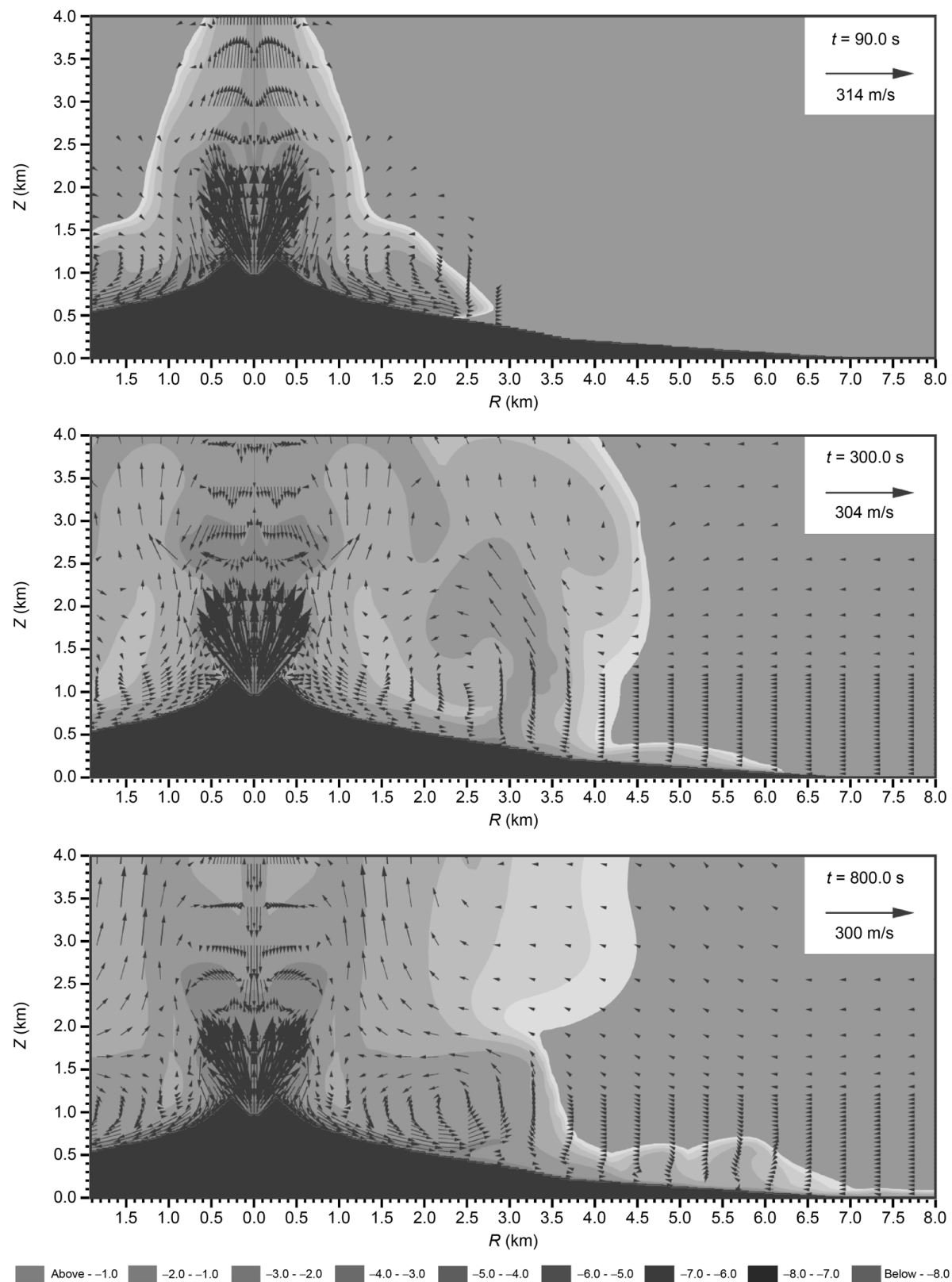

Fig. 2. Distribution of total particle volumetric fraction and gas flow velocity at 90,300 and $600 \mathrm{~s}$ from the beginning of the collapse for a pyroclastic-flow-generating volcanic column at Vesuvius. The simulation scale is representative of a sub-Plinian type eruption at Vesuvius similar to the 1631 eruption. The topographic profile assumed in the simulation is representative of the southern sector of Vesuvius. Contour levels refer to the exponents to the base 10 of particle concentration and correspond to value of $-8,-7,-6,-5,-4,-3,-2$, and -1 (modified from Todesco et al., 2002). 
Firstly, the peculiar nature of volcanic processes requires the formulation of more physicallysound models. For example, the influence of dispersed particles on the turbulence of the carrier phase (turbulence modulation), and particle-particle interactions in the poly-dispersed mixtures need to be more accurately described. Secondly, experimental research - both in the laboratory and in the field - is necessary to improve the equations of physical, thermal, and rheological properties, and to better validate the theoretical models. Thirdly, the development of more effective numerical techniques, including the use of parallel computing, are necessary to allow the simulation of more realistic events in three dimensions and for longer simulation times. Finally, the simulation of the dynamics of larger particles such as lapilli or clasts remains a challenge, because the continuum assumption is no longer applicable (see for instance Wilson, 1972; Fagent and Wilson, 1993; Lo Savio, 2004).

\section{Simulation of the eruption column and the distal environment on the mesoscale-beta $(20-200 \mathrm{~km}$ - some hundreds of minutes)}

Numerical simulations of atmospheric processes on the mesoscale-beta require description of the conditions both within the eruption column and in its local environment. The high velocities, temperatures, particle concentrations, and large gradients in an eruption column complicate the solution of the equation algorithm that describes the eruption dynamics and thermodynamics. Conditions in the dispersing plume and background atmosphere are less vigorous, and do not necessitate such a complex algorithm. The comprehensive models described in the previous section are currently much too demanding in terms of computer time and memory to simulate eruption column and advected cloud dispersal on longer time scales or to consider a higher number of column processes, e.g., microphysics or chemistry. Various numerical models exist for simulation of larger scale atmospheric flows on the mesoscale-alpha. These are used for simulation of phenomena like air pollution dispersion, atmospheric boundary layer or cloud processes, and also for far-field ash dispersal modelling, as discussed in the next section. Yet many of the simplifying assumptions applied in atmospheric models are not valid for the high-energy processes close to the vent and in the rising column. Thus models were developed specifically for the simulation of the eruption column and subsequent dispersal, based on novel concepts reviewed hereafter.

The first studies of the fluid dynamics of buoyant plumes built upon the seminal work of Morton et al. (1956). They derived a simple formula for the first-order estimation of plume height based on the relation between the erupted buoyancy flux, which is associated with the temperature and the mass, and the atmospheric stratification. The Morton formula, neglecting the increased stability of the stratosphere, shows a fairly good agreement with observations for the limit case of powerful plumes in comparatively negligible wind (see Sparks et al., 1997). The analytical studies of Wilson (1976), Sparks and Wilson (1982), and others provided insights into the structure of eruption columns. Time-averaged, Gaussian profiles are assumed at each height for quantities like temperature, velocity, and particle concentration. Interactions between components of the fluid are neglected; the gasparticle mixture is treated as a homogenous mixture, similar to fine-grained, diluted columns. Based on these assumptions, one-dimensional, steady-state models were developed (Wilson and Walker, 1987; Woods, 1988, 1993), which solve the equations of conservation for mass, momentum, and heat, accounting for separate components (e.g., dry air, water vapour, liquid condensates, and solid particles) within the homogenous fluid approximation. Turbulent mixing (i.e. entrainment) into the eruption column is determined by an entrainment parameter, which relates entrainment to the upward velocity in the column. Such models are suitable for steady state eruptions, e.g., so-called dry plinian eruptions with a low occurrence of liquid water (Sparks et al., 1997). They have been useful for first estimations of plume dynamics, like vertical density and velocity profiles, and for understanding transition between collapsing and non- 
collapsing flows. For comprehensive overviews see Sparks et al . (1997), or Woods (1998). Models of this type have been employed for a variety of applications, like the assessment of the influence of the ambient conditions on the plume height (Glaze and Baloga, 1996), or for the investigation of extraterrestrial volcanic eruptions (Glaze and Baloga, 2002). In spite of its quite coarse assumptions, this model type has been employed for important first estimations about the injections of water vapour (Glaze et al., 1997) and volcanic gases (Tabazadeh and Turco, 1993) into the stratosphere. It has recently been used for the investigation of particle recycling and aggregation in volcanic plumes (Veitch and Woods, 2000, 2001, 2002). The limitations of utilizing a one-dimensional, steady state model for these kinds of questions were discussed in detail by Textor and Ernst (2004) and by Veitch and Woods (2004).

The dispersion and sedimentation of tephra in the proximal region of the volcano were examined with sedimentation models, which focus on the fallout of ash from the margins of turbulent particle-fluid suspensions. They use simple relationships derived from the work of Morton et al. (1956) to calculate the variation of the plume width and speed with height. The growth of the umbrella cloud is also modelled as a function of time (Sparks et al., 1997). The dynamics in the eruption column is not explicitly predicted although it relates to first principles and sound experimental insights (e.g., Martin and Nokes, 1988). Microphysical processes are not considered. Far-field dispersal was then simulated by others under the assumption that it is dominated by atmospheric motions, and can be described by the turbulent advection-diffusion equation in different degrees of completeness. The effects of different plume geometries, atmospheric stratification, crosswind and re-entrainment, and particle aggregation were investigated in detail. For comprehensive overviews see Sparks et al. (1997), or Bursik (1998).

More recently a further model class became available, in which both the rise of the eruption column from the lithosphere to the stratosphere, and the dispersal of the plume of volcanic particles and gases are simulated. Calculations on time scales of hours covering spatial scales of hundreds of kilometres, and the inclusion of a higher number of transported quantities and processes necessitate some simplifications in contrast to the multiphase flow models described in the previous section. This is realized within the concept of the model ATHAM (Active Tracer High resolution Atmospheric Model) (Herzog et al., 1998; Oberhuber et al., 1998; for a different approach see Suzuki et al., 2005). The ATHAM model is a non-hydrostatic model solves the full set of Navier-Stokes equations for the multiphase system. The temporal evolution of the volcanic eruption cloud in the atmosphere is now simulated, including unsteady eruptions. Tracers (liquid and solid particles and gases) are not passively transported with the mean flow as in usual atmospheric models, because they can be locally highly-concentrated in the erupted gas-particle mixture. These 'active tracers' influence the dynamics by altering the mixture's density and heat capacity.

The system description requires a large set of dynamic and thermodynamic equations for each component and the interactions between them. However, on the condition that all particles are smaller than about a millimetre, it can be assumed that the gas-particle mixture is in thermal and in dynamical equilibrium. Under these assumptions, the equations have to be solved for volume mean quantities only (but different tracers can still have different fall velocities). To avoid conflicts with the model assumptions processes in the high pressure, hot temperature regime within and close to the crater cannot be modelled, and vent topography is neglected. However, the inclusion of a higher number of tracers and processes, and longer simulation times are possible. A turbulence closure scheme describes sub-scale processes in the eruption column (Herzog et al., 2003). Examinations of specific processes and of the parameters controlling them within the rising column and associated ash cloud were carried out. These included investigations focusing on the influence of the ambient conditions upon plume development (Graf et al., 1999), on cloud microphysics (Herzog et al., 1998), gas scavenging (Textor et al., 2003b,c) and ash aggregation (Textor et al., 2005a,b).

In order to perform numerical simulations, the equation system describing the eruption has 


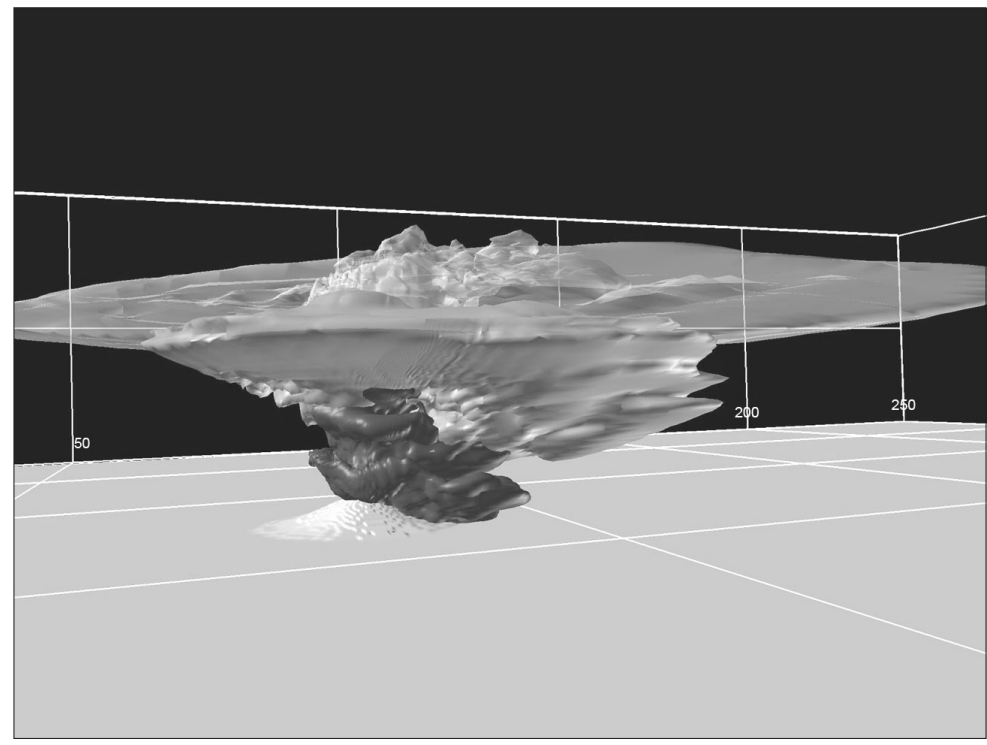

Fig. 3. Eruption column of volcanic ash after $30 \mathrm{~min}$ of simulation with ATHAM. The dimensions of the grid are $50 \mathrm{~km}$ in the horizontal and $25 \mathrm{~km}$ in the vertical direction. Three ash size classes are shown $(10 \mu \mathrm{m}, 200$ $\mu \mathrm{m}$, and $4 \mathrm{~mm}$ in radius), increasingly dark grey shading indicates the increase in size.

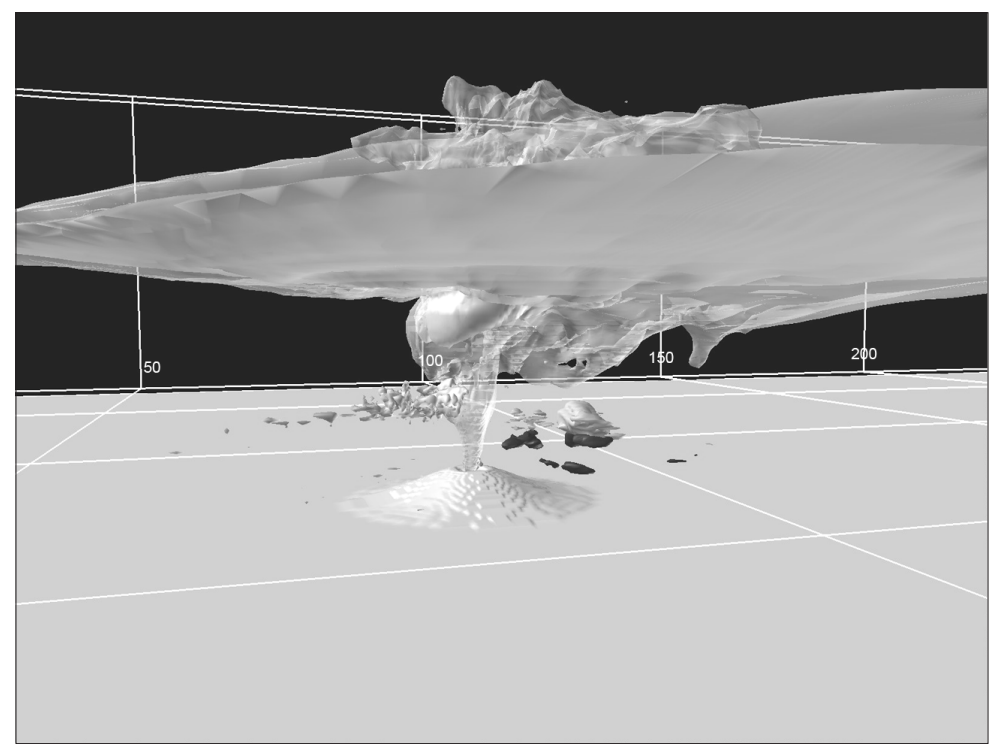

Fig. 4. Eruption column of fine volcanic ash and hydrometeors after 30 min of simulation with ATHAM. The dimensions of the grid are $50 \mathrm{~km}$ in the horizontal and $25 \mathrm{~km}$ in the vertical direction. The dark shading beside the column indicates liquid water. Ice and $10 \mu \mathrm{m}$ ash are indicated by the light grey shading. 
to be approximated 1) by discretisation in time and space, and 2) by applying advanced numerical techniques to integrate the system. Hence, the representation of sub-grid and simultaneous processes is a difficult issue. The ATHAM model has been validated for the simulation of a biomass burning plume (Trentmann et al., 2002). Key aspects of simulated explosive eruptions compare favourably to expectations based on first principles. We are currently rigorously evaluating ATHAM eruption simulations against fundamental observations from satellites and ground-based volcanological data. Results so far support ATHAM as a robust model. Figure 3 shows a simulated eruption column with ash of three different size classes, and fig. 4 illustrates the eruption column of fine ash and hydrometeors from an ATHAM model simulation at $30 \mathrm{~min}$ of eruption (Herzog et al., 2003).

Other numerical models focus on the source-dispersal relationship for volcanic gas emissions to the atmosphere. The link between geochemical analyses and remote sensing data helps to better understand the factors, which determine the source strength (e.g., Edmonds et al., 2001). A study on the atmospheric lifetime of $\mathrm{SO}_{2}$ by Oppenheimer et al. (1998) indicated that meteorological and geographic factors, as well as degassing rates, should be considered when interpreting measured $\mathrm{SO}_{2}$ fluxes.

Simulations of time-dependent processes within the eruption column and near-volcano environment at the same time can now be run in three dimensions (Herzog et al., 2003). The model results can be compared to observations in order to better understand the interactions of dynamics, turbulence, cloud and particle microphysics, and chemistry for different environmental and volcanic conditions. The parameterisations of individual processes employed in all these different models reflect the current state of knowledge about volcanic eruptions in the atmosphere. Sensitivity studies, where a single process or factor is modified, help to understand and better determine the complex interactions. The results from such simulations can then be utilized to design investigations of the most relevant quantities by laboratory and field experiments. In addition, the source strength of volcanic emissions can be estimated for differ- ent volcanic and environmental conditions. This information is essential for the assessment of the climate impact of volcanic emissions.

A more comprehensive representation of some processes like the microphysics of clouds and ash, or gas adsorption at particle surfaces should be envisaged in the future. The descriptions of volcanic particle properties (e.g., shape, porosity) during atmospheric transport have to be improved in accordance with new observations. The effects of electric fields within the volcanic eruption column have not been tackled by numerical simulation so far, but might be important for ash aggregation (e.g., Sparks et al., 1997; James et al., 2000).

\section{Atmospheric simulation of Ash dispersal on the mesoscale-alpha $(200-2000 \mathrm{~km}-$ some tens of hours), and on the regional scale}

Far-field dispersal is no longer determined by the eruption itself, but by atmospheric motions This motion can be described by the advectiondiffusion equation, as mentioned above for simulation of the proximal ash transport, often extended with special approximations for turbulent diffusion. The particle dispersion is simulated by a Lagrangian or a Eulerian formulation of advection, fallout and turbulent dispersion.

Ash tracking models have been used by various agencies to mitigate volcanic ash hazard. All these models simulate the movement of airborne ash using meteorological field data sets from observations or from other model simulations. These models include among others: Lagrangian Trajectory Volcanic Ash Tracking Model (PUFF) (http://puff.images.alaska.edu/ index.html); Nuclear Accident Model (NAME) (http://www.metoffice.gov.uk/research/nwp/ publications/nwp_gazette/dec00/name.html); Single-Particle Lagrangian Integrated Trajectory (HYSPLIT) model (http://www.arl.noaa.gov/ ready/hysp_info.html); Volcanic Ash Forecast Transport And Dispersion (VAFTAD) model (http://www.arl.noaa.gov/ss/models/vaftad.html); Hybrid Particle And Concentration Transport Model (HYPACT) (http://www.atmet.com/html/hypact_soft.shtml); CANadian Emergency Response 
Model (CANERM) (http://www.cmc.ec.gc.ca/cmc/ CMOE/vaac/pph/A-pph.html); TRAjectory of Volcanic materials (TRAV) and MEDIA (http:// www.meteo.fr/aeroweb/info/vaac/).

The focus of these models is the forecast of the location of the volcanic ash in space and time. Some of these models are operationally used by the nine Volcanic Ash Advisory Centres (VAACs) (ICAO, 2000), which serve as an interface between volcano observatories, meteorological agencies and air traffic control centres in order to prevent hazards to aircrafts.

Ash tracking models are not able to resolve the eruption column. They have to prescribe the initial spatial distribution of the ash cloud. In particular the cloud height and its variation with different atmospheric conditions is a crucial parameter for accurately forecasting ash dispersion (e.g., Tupper et al., 2003). However, it cannot be determined with sufficient accuracy by the observational systems currently in use. Hence, a quantitative estimation of the source strength based on volcanological parameters would be highly desirable (Chen, 2003). In addition, the ash dispersal models often have too coarse a resolution to accurately resolve smallscale weather phenomena, e.g., thunderstorms, and they do not include particle removal by precipitation, or ash aggregation. Wrong forecasts of ash dispersal lead to substantial over or under warning, and thus to enhanced risks and costs to the aviation industry (e.g., Casadevall, 1994; Grindle and Burcham, 2002, 2003; Simpson et al., 2002; Rose et al., 2003; Lacasse et al., 2003).

Ash emissions at many volcanoes, especially in least developed countries are unchecked and/or not quantified. Despite official multilateral agreements, regional VAACs are often informed about eruptions only after the event, when it is no longer hazardous for air traffic (e.g., A. Tupper, Darwin VAAC, pers. comm.). Ash emissions represent an increasing threat for international air traffic.

\section{Global simulations}

The main objective of simulations on the global scale is to understand the impact of large volcanic eruptions, which reached the stratosphere on atmospheric dynamics and chemistry. To assess the climate impact of volcanic eruptions, the interactions of volcanic sulphate aerosol particles with atmospheric dynamics, chemistry and radiation have to be treated accurately. For the calculation of the mutual feedback mechanisms between these components it is not sufficient to simply calculate the dispersal of the volcanic cloud. Instead, detailed representations of the formation and temporal development of the aerosol size distribution are required, which can be obtained in two ways. First, observed global fields of the volcanic aerosol size distribution (extinction, surface area density) can be used. Second, the aerosol microphysics processes can be explicitly calculated within the global model. These two approaches are illustrated in more detail below.

\subsection{Prescribed volcanic aerosol approach}

Atmospheric observations of volcanic aerosols have been collected for only 20 years. They include two major volcanic eruptions (El Chichón in April 1982 and Mt. Pinatubo in June 1991) and a few minor ones (e.g., Ruiz - 1985; Kelut - 1990; Hudson - 1991; Spurr - 1992; Nyamuragira - 2001). In particular, the dispersal of the Pinatubo cloud and the subsequent changes in the atmospheric system (temperature, trace gas concentration) were detected by in situ airborne and remote sensing measurements (lidar and satellite). Global simulations with General Circulation Models (GCMs), which used such observed volcanic aerosol fields, mainly addressed the Pinatubo and the El Chichón eruptions (e.g., Graf et al., 1993; Kirchner et al., 1999; Ramachandran et al., 2000; Stenchikov et al., 2002; Collins, 2003; Shindell et al., 2003). Chemistry climate models (Al-Saadi et al., 2001; Rozanov et al., 2002) and 2D chemical radiative transport models (Kinnison et al., 1994; Rosenfield et al., 1998) focused on the Pinatubo aerosol impact upon stratospheric trace gas concentrations.

Model studies investigating the climate impact of volcanoes on centennial and decadal time scales use monthly and latitudinal varying 
data sets of volcanic forcing (e.g., Sato et al., 1993; Andronova et al., 1999; Crowley, 2000; Robertson et al., 2001) which are based on observations (phyrheliometric measurements of atmospheric extinction, and since 1979 satellite data) and ice core data. Recently, Amman et al. (2003) published a monthly volcanic forcing data set for climate modelling from 1890 to 1999. Aerosol from each event is individually evolved spatially at monthly resolution derived from off-line calculations. These are based on an observed peak aerosol loading and a simple parameterisation for the stratospheric aerosol time evolution and transport.

The advantage of using prescribed aerosol is the possibility to thoroughly study the atmospheric effects of eruptions in a computationally efficient way. This approach is, however, highly dependent on the quality and amount of available observations, which are only sufficient for the last two decades. It is difficult to assess the impact of past and future eruptions. The feedback of aerosol-induced radiative forcing and ozone changes on volcanic cloud transport cannot be addressed with the prescribed volcanic aerosol approach.

\subsection{Prognostic volcanic aerosol approach}

The formation and temporal development of the aerosol is simulated from the stratospheric input of volcanic gases. This requires detailed information on the timing, the eruption height, the amount of emissions, and the initial spatial dimensions of the volcanic cloud. The usage of a bulk aerosol model is the simplest way to simulate global dispersal. Simulations of the Pinatubo aerosol using such an approach (Young et al., 1994; Timmreck et al., 1999) showed that local in situ heating has an important effect on volcanic cloud transport. A number of bulk volcanic aerosol simulations have been performed for historical eruptions. Stevenson et al. (2003) studied the chemical impact of the 1783-1884 Laki fissure eruption, and Graf and Timmreck (2001) investigated radiative forcing by the Laacher See eruption (10990 BP).

The capability of aerosol simulations using a bulk approach as described above for the assess- ment of atmospheric effects of volcanic eruptions is however limited by the lack of knowledge about the aerosol size distribution. Information on formation and temporal development of the aerosol size distribution and chemical composition are needed for more realistic radiation as well as chemistry calculations. This requires the treatment of aerosol microphysical processes in the global model. The microphysical processes to be considered are the formation of new particles due to binary homogeneous nucleation of $\mathrm{H}_{2} \mathrm{SO}_{4} / \mathrm{H}_{2} \mathrm{O}$, condensation and evaporation of $\mathrm{H}_{2} \mathrm{SO}_{4}$ and $\mathrm{H}_{2} \mathrm{O}$, Brownian coagulation, gravitational sedimentation, dry deposition and the wet removal of the particles due to incloud and below cloud scavenging.

In the last years several simulations of volcanic eruptions with two dimensional chemistry transport models including sulphate aerosol microphysics were published. These studies focus on the impact of present day eruptions (Bekki and Pyle, 1994; Tie et al., 1994a,b; Weisenstein et al., 1997) but there exist also studies for past events (Bekki, 1995; Bekki et al., 1996). Chemistry models, which include aerosol microphysics together with the various interactions necessary to completely analyse the climatic impact of volcanic eruptions, are presently still missing. There are, however, first steps in that direction. Pitari and Mancini (2002) assessed the climate impact of the Pinatubo eruption with a global model, in which ozone and aerosols are transported, and aerosol microphysical processes are calculated explicitly. But they used a coupled model system consisting of a chemistry transport model and a global circulation model, so that not all interactions were fully included Timmreck et al. (2003) used a chemistry climate model with interactive and prognostic volcanic aerosol and ozone to study the same eruption. They did not calculate microphysical processes explicitly, but treated aerosol mass as prognostic variable and derive parameters for the aerosol size distribution from the aerosol mass using a parameterisation based on observed correlations between aerosol mass and surface. Figure 5 shows the global dispersal of the Pinatubo cloud simulated with the chemistryclimate model MAECHAM4 (Timmreck et al., 2003). 

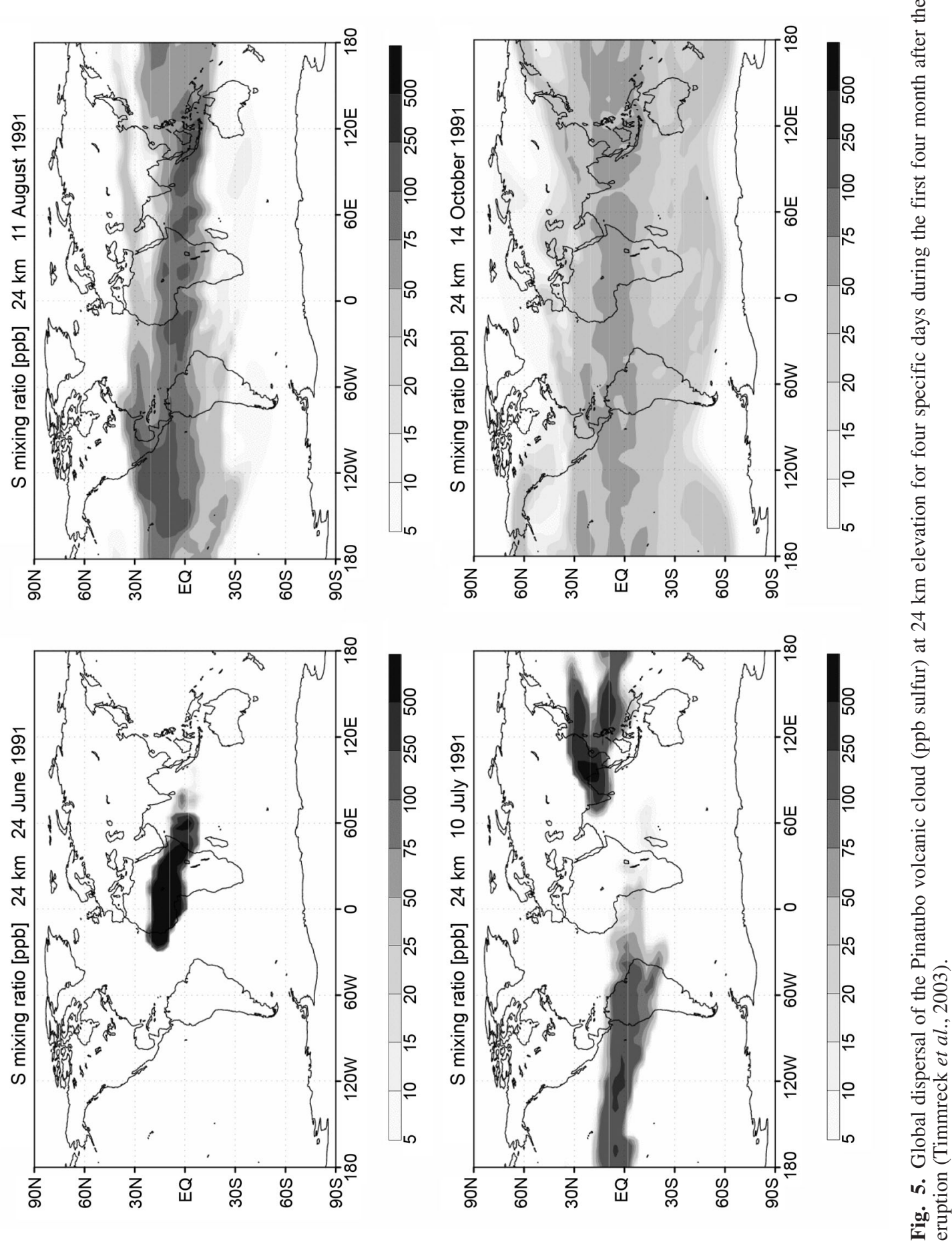
The advantage of the prognostic volcanic aerosol approach is the possibility to study atmospheric effects of explosive volcanic eruptions on the global scale, independently from existing observations. This gives the chance to perform sensitivity studies and to integrate future scenarios. However, as discussed above, a global model that treats all processes in a sophisticated manner is still missing. Information about the emissions of gases and ash, and about the column height is required for the simulation of volcanic eruptions. This information is commonly scarce, especially for past eruptions. Simulations with smaller scale numerical models can help to provide initial conditions, as discussed in detail in Section 7. In addition, it is worth mentioning that due to the coarse vertical (about 1-2 km) and horizontal resolution (several $100 \mathrm{~km}^{2}$ ) of global models, the dispersal of the volcanic cloud can only be coarsely represented, and some processes like stratospheretroposphere exchange or streamer transport might be critical points. Global prognostic aerosol simulations should not be mixed up with reality, but rather be considered as tools to study and understand the atmospheric effects of explosive volcanic eruptions.

Since the 1980s and up to recently, atmospheric scientists were exclusively interested in the impact of extreme volcanic eruptions that inject large amounts (1-10000 Mt) of volcanic emissions into the stratosphere and lead to climatic anomalies. Now, there is an increasing recognition that, not just large episodic events, but also the many small emissions and prolonged degassing at many volcanoes worldwide can also have an atmospheric (global sulphur budget) and climatic impact (Graf et al., 1997, 1998). Active volcanoes generally reach considerable elevations and most of their emissions are injected into the free troposphere, above the well-mixed Planetary Boundary Layer (PBL), which typically extends upward from the surface to several hundreds of meters. At high elevations above the PBL, removal processes are slower, and volcanic sulphur has thus longer residence times than anthropogenic sulphur, which is mostly emitted from low elevations. Consequently, the radiative effect on the atmosphere of volcanic sulphur is disproportionately larger than that of anthropogenic sulphur. This was illustrated by numerical experiments with atmospheric general circulation models including a simplified sulphur cycle (Graf et al., 1997).

Furthermore, tropospheric sulphate aerosols act as Cloud Condensation Nuclei (CCN) and modify the radiative properties and lifetime of clouds (Twomey, 1974). The increase in cloud droplet number concentration due to the CCN enhancement in turn increases cloud albedo, enhancing surface cooling. Knowledge of these effects can affect our ability to accurately predict the global climate and its evolution.

In the absence of continuous monitoring of volcanic degassing on the global scale, the total amount of volcanic sulphur emissions in the troposphere is highly uncertain and still under discussion (see for details e.g., Textor et al., 2003a). A comprehensive dataset of volcanic degassing into the troposphere is needed to improve global models. The ideal dataset would not only include explosive events, which can partly be observed by satellite, but also longterm low-level degassing from craters, lava lakes, lava domes, fumarolic activity and dissipative emissions at the volcano flanks. Although some promising studies are available, such a data set is currently missing. The representations of the tropospheric sulphur cycle in global atmospheric models still differ between the models (Barrie et al., 2001; Lohmann et al., 2001) mainly due to the contrasting complexity of the tropospheric chemistry accounted for.

\section{Discussion}

A profound knowledge of the fluxes and species distribution of volcanic emissions is essential for the assessment of the effects of volcanic eruptions in the atmosphere. It is a major challenge to establish a volcanic observation network, which would deliver all information needed to create a data set with complete spatial and temporal coverage on the global scale, because of the high temporal, spatial and intensity variability of volcanic emissions. Extreme differences exist between the eruption styles of volcanoes of different types, but also between 
the phases of activity for volcanoes of the same type. These differences aggravate the principal understanding of the volcanic system, and thus the extrapolation of observational data to nonmonitored volcanoes. Volcanic emissions are the consequence of a long-term evolution. Precise understanding of the current state of a given volcano regarding its eruptive cycle and further evolution requires the collection of long time series of high quality data.

Important fieldwork has been done at individual volcanoes in recent decades, although the majority of active volcanoes (perhaps $80 \%$ of them), which are in least developed countries, remain unstudied.

Laboratory experiments provided essential information on the eruption dynamics and the chemistry of the magmatic system. Numerical models are based on and constrained by the findings of these studies, and simulation results should be carefully validated against observational data. Systematic field and observational studies are rather scarce or virtually inexistent. Much more systematic petrological and field volcanological data need to be collected so that new predictions of complex conduit and source processes can be independently tested. Equally, eruption and deposit parameters, ash cloud dispersal, and time dependent characteristics should be investigated and quantified. A database of the emissions from thousands of fluctuating low level volcanic gas sources as well as from the largest of eruptions is needed in order to improve our understanding of the volcanic impact on the global environment.

Once they have been carefully validated, numerical models can be employed for a variety of tests and sensitivity studies, which partly substitute time consuming, expensive, dangerous or even impossible experiments and observations. There are generally two main approaches to numerical modelling, which also pertain to the simulation of volcanic eruptions.

In the first approach one attempts to simulate an event under a certain aspect, like aircraft safety, or climate effects. The comprehensiveness and the lack of understanding (or of computer power) of volcanic eruptions make it impossible to set up and analytically solve an equation system, which entirely describes all relevant processes. As a last resort, simplifying parameterisations, that is, empirical descriptions of the natural processes are employed. Obviously, even sophisticated semi-empirical predictions can only be as good as the database used to derive them. Furthermore, this method is based on the assumption that the net result of a partly parameterised system can substitute a complex analytical simulation of the real system. The main target of such modelling is to provide the quantitative information needed for policy makers concerned with risk mitigation to tackle questions of practical and sometimes urgent public concerns. An example is the estimation of the extent of high-risk areas around highly-populated volcanoes like Montserrat based on numerical simulations (see e.g., Bonadonna et al., 2002).

The second approach, in contrast, typically isolates a few parameters, which are thought to mainly control the system. These parameters are then examined within an idealistic model of the real system, typically through analytical modelling or laboratory analogue experiments. The obvious limitation of this second approach to numerical modelling is that it ignores many other parameters, of which the importance cannot be known a priori. Such idealistic models are not directly usable to solve practical problems as in the parameterised models mentioned above. The relative simplicity of these models allows, however, insights on the fundamental mechanisms controlling volcanic eruptions and their impacts. The method helps to understand individual controls, which can then be evaluated rigorously against observations as well as the other forms of simple modelling on the same aspect. This way, one hopes to explore the system in a step-by-step approach. An example of this second approach can be found in the publications of Ernst et al. (1996), or Melnik and Sparks (2002a,b).

The two approaches to numerical simulations introduced here serve complementary purposes and are both helpful and needed. The models described in this contribution are rather based on the first approach, since they are not purely analytical models. However, important advances in understanding volcanic eruptions and in computing facilities allow nowadays for the formulation of 
increasingly comprehensive models. A large progress was achieved since the development of the first, simple one-dimensional homogeneous and steady-state models. Today, complex multidimensional multiphase, transient models provide more accurate hazard assessment, and they can also be utilized to identify single relevant parameters, e.g., in sensitivity studies, when single parameters are modified (see for example Neri et al., 2003; Textor et al., 2003c). This latter type of numerical simulations can be regarded as a hybrid of the two approaches.
We have presented models for numerical simulations of volcanic eruptions on different scales, tracking volcanic emissions during transport from the lithosphere to the stratosphere, finally influencing the global climate. Explosive volcanic eruptions and their effects on the ground and in the atmosphere cannot be simulated by one single model, because of the complexity of the topic and contrasting spatial and temporal scales involved. However, the individual models presented in this paper cover many relevant processes and scales. The com-

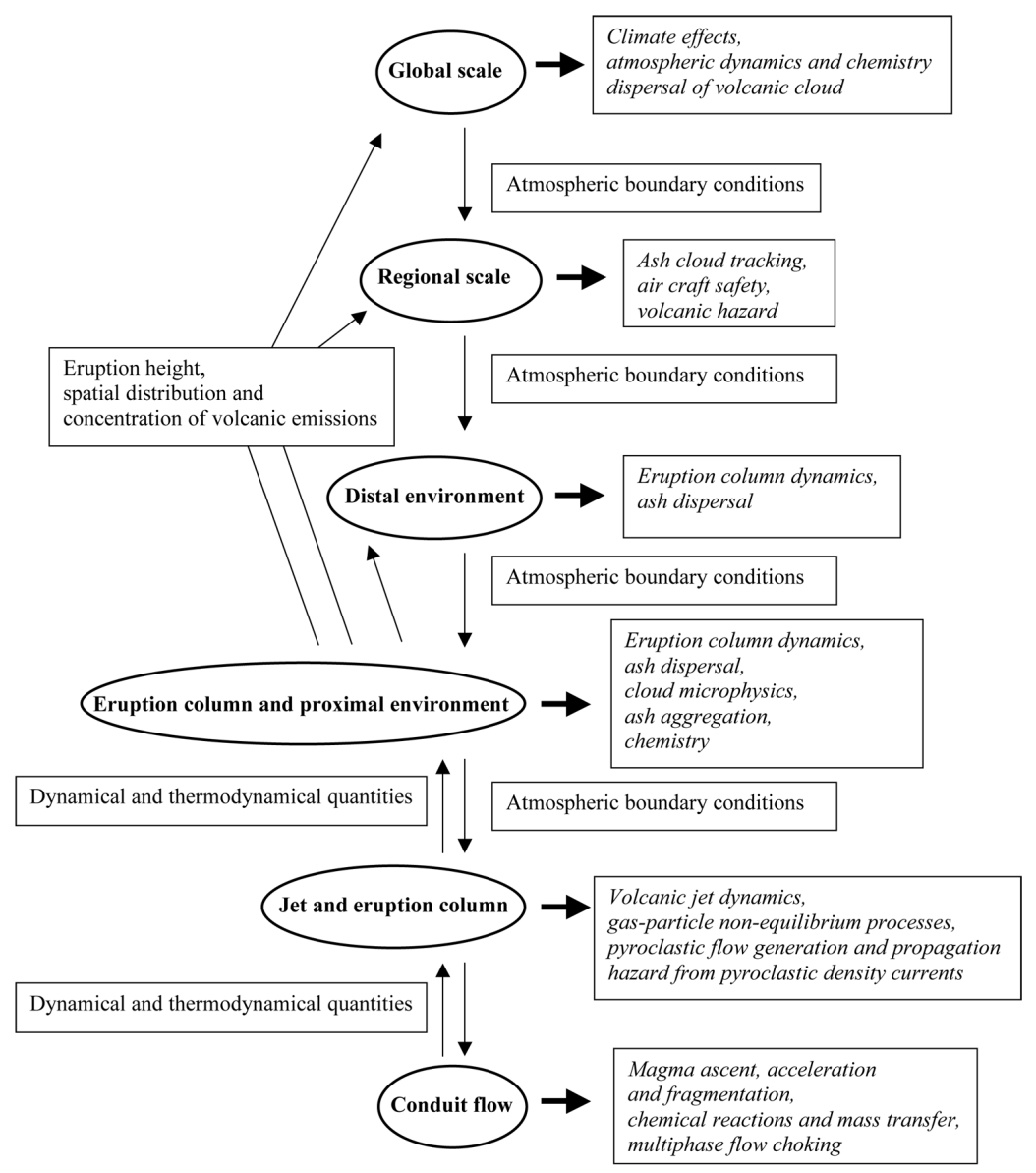

Fig. 6. Schematic representation of the chain of numerical models of volcanic eruptions on different spatial scales. The regions of interest are indicated in bold letters in the central oval boxes. The focus of each model is described in the right boxes in italics. Possible interactions between them can be found beside the vertical arrows. 
bination of these tools provides the unique possibility to derive a more comprehensive description of the volcanic system.

Due to the difficulty or impossibility of observing many processes and parameters during a volcanic eruption, numerical simulations are especially insightful in the investigation of the system's complexity. Model results have to be carefully validated with observations, and no model can be better than comprehensive observations. Quantities or processes, which are not amenable to measurements, and which cannot be calculated within one model, are simulated in detail by another one. Figure 6 summarizes the chain of models, which is now available for the investigation of explosive volcanic eruptions on a broad range of spatial and temporal scales. The sizes of the model domains increase from the bottom to the top, along with a decrease of the spatial and temporal resolution. Each model has been developed for a specific area of research, and each of them is based on a different set of equations and parameterisations, valid for the specific model applications, shown in the boxes to the right. The potential for the mutual exchange of simulation results is indicated beside the vertical arrows. The smaller-scale models can provide information about the volcanic forcing for the larger ones, which in turn can supply information on the atmospheric conditions for the smaller-scale models.

Results from a conduit ascent model can be used to determine the volcanic forcing at the vent for the simulation of ash dispersal and microphysical processes within the eruption column, to explore the influence of magmatic properties on the eruptive style. Models focusing on the jet region, in turn, provide the boundary conditions for dynamical variables describing the volcanic forcing (e.g., temperature, vertical velocity) in larger scale eruption column models, because these models are not able to sufficiently resolve the region closest to the vent. The eruption heights gained from the simulations with the ATHAM model, for example, are found to be highly sensitive to the initial conditions at the base of the eruption column after equilibration to atmospheric pressure. Up to now, the initial vertical velocity, the gas fraction, and the horizontal extension, which cannot be directly observed during a violent eruption, had to be estimated based on theoretical considerations. The use of data gained from conduit models connected with those focusing on the jet region will reduce this uncertainty, and we intend to perform such joint experiments.

The initial spatial distribution and concentration of the volcanic cloud for larger-scale simulations, or for global simulations in climate change research can be obtained from eruption column models. The injection height is a crucial parameter for the further dispersal and atmospheric residence time of volcanic material, which is, in turn, crucial for aircraft safety and climate impacts. The injection height cannot be measured with the desired accuracy by the current observation techniques (e.g., Holasek et al., 1996; Oppenheimer, 1998), and can only be inverted with $20-30 \%$ error from tephra fall deposit characteristics of past eruptions (e.g., Bonadonna et al., 1998, and references therein). High uncertainties exist about the proportion of gases and particles erupted, which reach the stratosphere and influence the global climate. These uncertainties are caused by the difficulties of directly observing the processes within explosive volcanic eruption clouds, and by the lack of fundamental studies in an extreme parameter regime. Simulations with eruption column models perfectly fill in this gap, since they focus on the investigation of processes, which could otherwise not be accessed. We plan, for example, a consecutive study where we investigate the impact of the water vapour and ice injection calculated by an eruption column model on the microphysics and chemistry in the stratosphere calculated by a global model.

\section{Conclusions}

In recent years, numerical simulation of volcanic eruptions has greatly advanced. However, because of the complexity and the various scales involved, not all processes could be addressed so far. Different models have been developed, which each work best over a limited and contrasting range of spatial and temporal scales. These models focus on different eruption processes and phases. The existence of 
such a chain of increasingly advanced models offers a new opportunity to explore the various aspects of the volcanic system in a joint effort in combination with various experimentations and observations both in the laboratory and in the field. We plan such an effort in the future, exploring the linking of the results from simulations with the various models. This may reduce uncertainties in assessing the environmental and climate impact of eruptions.

\section{Acknowledgements}

G.G.J. Ernst thanks the 'Fondation Belge de la Vocation' for a supporting award (Golden Clover Prize) and acknowledges support as a researcher at Gent by the Belgian NSF (FWO Vlaanderen). A. Neri and P. Papale have benefited from the funds of GNV-INGV Projects 200103/9 and 2001-03/17. C. Textor acknowledges support by the Volkswagen Foundation under the project EVA, the Max-Planck-Institute for Meteorology, Germany, and the Laboratoire des Sciences du Climat et de l'Environnement, France. The work of C. Timmreck was supported by the BMBF project KODYACS (Grant 07ATF43) and by the European Commission grant EVK2-CT-2001-000112 (project PARTS).

\section{REFERENCES}

Al-Saadi, J., R.B. Pierce, T.D. Fairlie, M.M. Kleb, R.S. ECKMAN, W.L. Grose, M. NATARAJAN and J.R. Olson (2001): Response of middle atmosphere chemistry and dynamics to volcanically elevated sulfate aerosol: three-dimensional coupled model simulations, J. Geophys. Res., 106 (D21), 27,255-27,276

Amman, C.M., G.A. MeEhl, W.M. Washington and C.S. ZENDER (2003): A monthly and latitudinally varying volcanic forcing dataset in simulations of 20th century climate, Geophys. Res. Lett., 30, 1657, doi:10.1029/ /2003GL016875.

Andronova, N.G., E. Rozanov, F. YANG, M.E. Schlesinger and G.L. STENCHIKOV (1999): Radiative forcing by volcanic aerosols from 1850 through 1994, J. Geophys. Res., 104, 16807-16826.

Ansmann, A., F. Wagner, U. Wandinger, U. Goersdorf and J. REICHARDT (1996): Pinatubo aerosol and stratospheric ozone reduction, J. Geophys. Res., 101 (D13), 18775-18785.

Ansmann, A., I. Mattis, U. Wandinger, F. WAgner and J. REICHARDT (1997): Evolution of the Pinatubo aerosols: Raman lidar observations of particle optical depth, ef- fective radius, mass and surface area over Central Europe at 53.4 $4^{\circ} \mathrm{N}$, J. Atmos. Sci., 54 (22), 2630-2641.

Barrie, L.A., Y. Yi, W.R. LEaItch, U. Lohmann, P. Kasibhatla, G.-J. Roelofs, J. Wilson, F. McGovern, C. Benkovitz, M.A. Mélières, K. LAW, J. Prospero, M. Kritz, D. Bergmann, C. Bridgeman, M. Chin, J. Christensen, R. Easter, J. Feichter, C. Land, A. Jeuken, E. KJellström, D. KoCH and P. RASCH (2001): A comparison of large-scale atmospheric sulphate aerosol models (COSAM): overview and highlights, Tellus Ser. B, 53 (5), 615-645.

BaXter, P.J., C. Bonadonna, R. Dupree, V.L. Hards, S.C. Kohn, M.D. Murphy, A. Nichols, R.A. Nicholson, G. Norton, A. SEarl, R.S.J. Sparks and B.P. Vickers (1999): Cristobalite in volcanic ash of the Soufrière Hills Volcano, Montserrat: hazards implications, Science, 283, 1142-1145.

BEKKI, S. (1995): Oxidation of volcanic $\mathrm{SO}_{2}$ : a sink for stratospheric $\mathrm{OH}$ and $\mathrm{H}_{2} \mathrm{O}$, Geophys. Res. Lett., 22, 913-916.

BeKki, S. and J. A. Pyle (1994): A two-dimensional modeling study of the volcanic eruption of Mt. Pinatubo, $J$. Geophys. Res., 99, 18,861-18,869.

BekKi, S., J.A. Pyle, W. Zhong, R. Toumi, J.D. Haigh and D.M. PYLE (1996): The role of microphysical and chemical processes in prolonging the climate forcing of the Toba eruption, Geophys. Res. Lett., 23, 2669-2672.

Bluth, G.J.S., S.D. Doiron, C.C. Schnetzler, A.J. KRUEGER and L.S. WALTER (1992): Global tracking of the $\mathrm{SO}_{2}$ clouds from the June, $1991 \mathrm{Mt}$. Pinatubo eruptions, Geophys. Res. Lett., 19, 151-154.

Bluth, G.J.S., C.C. Schnetzler, A.J. Krueger and L.S. WALTER (1993): The contribution of explosive volcanism to global atmospheric sulphur dioxide concentrations, Nature, 366, 327-329.

Bonadonna, C., G.G.J. ERnst and R.S.J. Sparks (1998): Thickness variations and volume estimates of tephra fall deposits: the importance of particle Reynolds number, J. Volcanol. Geotherm. Res., 81, 173-187.

Bonadonna, C., G. MACEDONIO and R.S.J. SPARKS (2002): Numerical modelling of tephra fallout associated with dome collapses and vulcanian explosions - Application to hazard assessment on Montserrat, in The Eruptions of Soufrière Hills Volcano, Montserrat, from 1995 to 1999 , edited by T.H. DruitT and B.P. KOKELAAR, $G e$ ol. Soc. London, Mem., 21, 517-537.

Bobrowski, N., G. Hönninger, B. Galle and U. Platt (2003): Detection of bromine monoxide in a volcanic plume, Nature, 423, 273-276, doi:10.1038/nature01625.

Buresti, G. and C. CASARosa (1989): One-dimensional adiabatic flow of equilibrium gas-particle mixtures in long vertical ducts with friction, J. Fluid Mech., 203, 251-272.

BursiK, M.I. (1998): Tephra dispersal, in The Physics of Explosive Volcanic Eruptions, edited by J.S. GILBERT and R.S.J. Sparks, Geol. Soc., London, Spec. Publ., 145, 115-144.

BursiK, M.I., S.N. CAREY and R.S.J. SPARKS (1992a): A gravity current model for the May 18, $1980 \mathrm{Mt}$. St. Helens plume, Geophys. Res. Lett., 19, 1663-1666.

BursiK, M.I., R.S.J. SPARKS, J.S. GILBERT and S.N. CAREY (1992b): Sedimentation of tephra by volcanic plumes, I. Theory and its comparaison with a study of the Fogo 
a plinian deposit, Sao Miguel (Azores), Bull. Volcanol., 54, 329-344.

CAREY, S., and R.S.J. Sparks (1986): Quantitative models of the fallout and dispersal of tephra from volcanic eruption columns, Bull. Volcanol., 48, 109-125.

CArroll, M.R. and J.R. Holloway (Editors) (1994): Volatiles in magmas, Rev. Mineral., 30, pp. 517.

Casadevall, T.J. (1994): The 1989-1990 eruption of Redoubt Volcano, Alaska: impacts on aircraft operations, J. Volcanol. Geotherm. Res., 62, 301-316.

Chen, P. (2003): Modeling volcanic ash transport and dispersion: expectations and reality, in WMO/ICAO Third International Workshop on Volcanic Ash, September 29-October 3, 2003, Toulouse, France.

Chouet, B. (2003): Volcano seismology, Pure Appl. Geophys., 160, 739-788.

Clarke, A., B. Voight, A. Neri and G. Maceonio (2002): Transient dynamics of vulcanian explosions and column collapse, Nature, 415, 897-901.

Collins, M. (2003): Predictions of climate following volcanic eruptions, in Volcanism and the Earth's Atmosphere, edited by A. Roвock and C. OPPENHEIMER, Am. Geophys. Un. Monogr., 139, 283-300.

Costa, A. and G. MAcEDONIO (2003): Viscous heating in fluids with temperature-dependent viscosity: implications for magma flows, Nonlinear Processes Geophys., 10, 1-12.

Crowley, T.J. (2000): Causes of climate change over the past 1000 years, Science, 289, 270-277.

Dartevelle, S., G.G.J. Ernst, J. Stix and A. Bernard (2002): Origin of the Mt. Pinatubo climactic eruption cloud: implications for volcanic hazards and atmospheric impacts, Geology, 30, 663-666.

Di Muro, A., A. Neri and M. Rosi (2004): Contemporaneous convective and collapsing eruptive dynamics: the transitional regime of explosive eruptions, Geophys. Res. Lett., 31, doi: 10.1029/2004GRL019709.

DingwelL, D.B. (1998): Recent experimental progress in the physical description of silicic magma relevant to explosive volcanism, in The Physics of Explosive Volcanic Eruptions, edited by J.S. GILBERT and R.S.J. Sparks, Geol. Soc., London, Spec. Publ., 145, 9-26.

Dingwell, D.B. and S.L. WebB (1989): Structural relaxation in silicate melts and non-Newtonian melt rheology in igneous processes, Phys. Chem. Min., 16, 508516.

Dobran, F., A. NERI and G. MACEDONIO (1993): Numerical simulation of collapsing volcanic columns, J. Geophys Res., 98, 4231-4259.

Dobran, F., A. Neri and M. Todesco (1994): Assessing pyroclastic flow hazard at Vesuvius, Nature, 367, 551554.

DruitT, T.H. and B.P. KoKElAar (Editors) (2002): The eruption of Soufrière Hills Volcano, Montserrat, from 1995 to 1999, Geol. Soc. Lond. Mem., 21, 1-645.

Durant, A.J. and G.G.J. ERNST (2003): Formation of accretionary lapilli as volcanogenic hailstones, Bull. Volcanol. (in review).

Edmonds, M., D. Pyle and C. Oppenheimer (2001): A model for degassing at the Soufrière Hills Volcano, Montserrat, West Indies, based on geochemical data, Earth Planet. Sci. Lett., 186 (2), 159-173.

ERnst G.G.J., J.P. DAVIS and R.S.J. SPARKS (1994): Bifur- cation of volcanic plumes in a crosswind, Bull. Volcanol., 54, 159-169.

ERnst, G.G.J., S.N. CAREY, M.I. BuRsiK and R.S.J. SPARKS (1996): Sedimentation from turbulent jets and plumes, J. Geophys. Res., 101, 5575-5589.

Esposti Ongaro, T., A. Neri, M. Todesco and G. MacedoNIO (2002): Pyroclastic flow hazard assessment at Vesuvius by using numerical modeling, 2. Analysis of flow variables, Bull. Volcanol., 64, 178-191.

FAGENT, S.A. and L. WiLson (1993): Explosive volcanic eruptions, VII. The ranges of pyroclasts ejected in transient volcanic explosions, Geophys. J. Int., 113, 359370 .

GidAsPow, D. (1994): Multiphase Flow and Fluidization: Continuum and Kinetic Theory Descriptions (Academic Press, New York), pp. 467.

GilberT, J.S. and R.S.J. SPARKS (Editors) (1998): The physics of explosive volcanic eruptions, Geol. Soc., London, Spec. Publ., 145, 115-144.

GLAZE, L.S. and S.M. BALOGA (1996): Sensitivity of buoyant plume heights to ambient atmospheric conditions: Implications for volcanic eruption columns, J. Geophys. Res., 101, 1529-1540.

GlaZE, L.S. and S.M. BALOGA (2002): Volcanic plume heights on Mars: limits of validity for convective models, J. Geophys. Res., 107 (E10) 5086.

Glaze, L.S., S.M. BALOGA and L. WILSON (1997): Transport of atmospheric water vapor by volcanic eruption columns, J. Geophys. Res., 102, 6099-6108.

GraF, H.-F. and C. TIMMreCK (2001): A general climate model simulation of the aerosol radiative effects of the Laacher See eruption (10900 B.C.), J. Geophys. Res., 106, 14,747-14,756.

Graf, H-F., I. Kirchner, A. Robock and I. Schult (1993): Pinatubo eruption winter climate effects: model versus observations, Climate Dyn., 9, 81-93.

Graf, H.-F., J. Feichter and B. Langmann (1997): Volcanic sulfur emissions: estimates of source strength and its contribution to the global sulfate distribution, $J$. Geophys. Res., 102, 10727-10738.

Graf, H.-F., B. LANGmann and J. Feichter (1998): The contribution of Earth degassing to the atmospheric sulfur budget, Chem. Geol., 147, 131-145.

Graf, H.-F., M. Herzog, J.M. Oberhuber and C. Textor (1999): The effect of environmental conditions on volcanic plume rise, J. Geophys. Res., 104 (D20), 24,309.

GRANIER, C. and G. BRASSEUR (1992): Impact of heterogeneous chemistry on model predictions of ozone changes, J. Geophys. Res., 97, 18015-18033.

GRINDLE, T.J. and F.W. BuRCHAM (2002): Even minor volcanic ash encounters can cause major damage to aircraft, Int. Civ. Aviat. Organ. J., 57 (2), 12-14.

GRINDLE, T.J. and F.W. BuRCHAM (2003): Engine damage to a NASA DC-8-72, airplane from a high-altitude encounter with a diffuse volcanic ash cloud, Tech. Memo. NASA/TM-2003-212030, pp. 27.

Groisman, P.Y. (1992): Possible regional climate consequences of the Pinatubo eruption: an empirical approach, Geophys. Res. Lett., 19, 1603-1606.

Herzog, M., H.-F. Graf, C. TeXtor and J.M. OBERhuber (1998): The effect of phase changes of water on the development of volcanic plumes, J. Volcanol. Geotherm. Res., 87, 55-74 
Herzog, M., J.M. Oberhuber and H.-F. Graf (2003): A Prognostic turbulence scheme for the nonhydrostatic plume model ATHAM, J. Atmos. Sci., 60 (22), 27832796.

Hofmann, D.J. and S. Solomon (1989): Ozone destruction through heterogeneous chemistry following the eruption of El Chichón, J. Geophys. Res., 94, 5029-5041.

HolaseK, R.E., S. SELF and A.W. Woods (1996): Satellite observations and interpretation of the 1991 Mt.Pinatubo eruption plumes, J. Geophys. Res., 101, 27635-27655.

Holloway, J.R. and J.G. BLANK (1994): Application of experimental results to $\mathrm{C}-\mathrm{O}-\mathrm{H}$ species in natural melts, in Volatiles in Magmas, edited by M.R. CARroll and J.R. Holloway, Mineral. Soc. Am., Rev. Min., 30, 187-230.

Horwell, C.J., I. Fenoglio, K.V. Ragnarsdottir, R.S.J. SPARKS and B. Fubini (2003a): Surface reactivity of volcanic ash from the eruption of Soufrière Hills volcano, Montserrat, with implications for health hazards, Environ. Res., 93, 202-215.

Horwell, C.J., R.S.J. SPARKs, T.S. BREwER, E.W. LlewelLIN and B.J. WILLIAMSON (2003b): The characterisation of respirable volcanic ash from the Soufrière Hills volcano, Montserrat, with implications for health hazards, Bull. Volcanol., 65, 346-362.

ICAO (International Civil Aviation Organization) (2000): Handbook on the International Airways Volcano Watch (IAVW): Operational Procedures and Contact List, $1 \mathrm{st}$ edition.

JAMES, M.R., J.S. GiLbERT and S.J. LANE (2000): Volcanic plume electrification: experimental investigation of a fracture-charging mechanism, J. Volcanol. Geotherm. Res., 105 (B7), 16641-16649.

Kinnison, D.E., K.E. Grant, P.S. Connell, D.A. Rotman and D.J. WuebBLES (1994): The chemical and radiative effects of the Mt. Pinatubo eruption, J. Geophys. Res., 99, 25,705-25,731.

Kirchner, I., G.L. StenchiKov, H.-F. Graf, A. Robock and J.C. ANTUNA (1999): Climate model simulation of winter warming and summer cooling following the 1991 Mt. Pinatubo eruption, J. Geophys. Res., 104, 19,039-19,055.

Klug, C., K.V. Cashman and C.R. Bacon (2002): Structure and physical characteristics of pumice from the climactic eruption of Mt. Mazama (Crater Lake), Oregon, Bull. Volcanol., 64, 486-501.

Lacasse, C., S. Karlsdóttir, G. Larsen, H. Soosalu, W.I. Rose and G.G.J. ERNST (2003): Weather radar observations of the Hekla 2000 eruption cloud, Iceland, Bull. Volcanol. (in press).

LiPMAN, P.W. and D.R. MulLinEAux (Editors) (1981): The 1980 eruptions of Mt. St. Helens, Washington, USGS Prof. Pap. 1250, 1-844.

Llewellin, E.W., H.M. MAder and S.D.R. Wilson (2002a): The rheology of a bubbly liquid, P. R. Soc. Lond. A Mat., 458 (2020), 987-1016.

Llewellin, E.W., H.M. MAder and S.D.R. Wilson (2002b): The constitutive equation and flow dynamics of bubbly magmas, Geophys. Res. Lett., 29 (24), 21702173.

Lohmann, U., W.R. Leaitch, L. Barrie, K. LaW, Y. Yi, D. Bergmann, C. Bridgeman, M. Chin, J. Christensen, R. Easter, J. Feichter, A. Jeuken, E. KJellstrøm, D. Koch, C. LAND, P. RASCH and G.J. RoElOFS (2001):
Vertical distributions of sulfur species simulated by large scale atmospheric models in COSAM: comparison with observations, Tellus Ser. B, 53, 646-672.

Lohmann, U., B. KÄRChER and C. TIMMRECK (2003): Impact of the Mt. Pinatubo eruption on cirrus clouds formed by homogeneous freezing in the ECHAM GCM., J. Geophys. Res., 108 (D18), 4568, doi: 10.1029/ 20002JD003185.

Lo SAVIO, S. (2004): Dinamica di lapilli e clasti piroclastici prodotti da eruzioni esplosive e implicazioni per il rischio vulcanico, Ph.D. Thesis, (Università degli Studi di Pisa).

Manga, M., J. Castro and K.V. Cashman (1998): Rheology of bubbole-bearing magmas, J. Volcanol. Geotherm. Res., 87, 15-28.

Martel, C., D.B. Dingwell and O. Spieler (2000): Fragmentation of foamed silicic melts: an experimental study, Earth Planet. Sci. Lett., 178, 47-58.

Martel, C., D.B. Dingwell and O. SpIELER (2001): Experimental fragmentation of crystal- and vesicle-bearing silicic melts, Bull. Volcanol., 63, 398-405.

Marti, J., C. Soriano and D.B. Dingwell (1999): Tube pumices as strani markers of the ductile-brittle transitino durino magma fragmentation, Nature, 402, 650653.

Martin, D. and R. NoKes (1988): Crystal settling in a vigorously convecting magma chamber, Nature, 332, 534536.

MAssol, H. and C. JAUPART (1999): The generation of gas overpressure in volcanic eruptions, Earth Planet. Sci. Lett., 166, 57-70.

Mastin, L.G. and M.S. GHIORSo (2000): CONFLOW - A numerical program for steady-state flow of magma-gas mixtures through vertical eruptive conduits, USGS Open-File Rep. 00-209.

McCormick, M.P., L.W. Thomason and C.R. Trepte (1995): Atmospheric effects of the Mt Pinatubo eruption, Nature, 373, 399-404.

Melnik, O. (2000): Dynamics of two-phase conduit flow of high-viscosity gas-saturated magma: large variations of sustained explosive eruption intensity, Bull. Volcanol., 62, 153-170.

Melnik, O. and R.S.J. SPARKS (2002a): Dynamics of magma ascent and lava extrusion at Soufrière Hills volcano, Montserrat, in The Eruptions of Soufrière Hills Volcano, Montserrat, from 1995 to 1999, edited by T.H. DRUiTT and B.P. KokelaAR, Geol. Soc. London Mem., 21, 153-171.

MelniK, O. and R.S.J. SPARKS (2002b): Modelling of conduit flow dynamics during explosive activity at Soufrière Hills volcano, Montserrat, in The Eruptions of Soufrière Hills Volcano, Montserrat, from 1995 to 1999 , edited by T.H. DruitT and B.P. KoKElaAR, Geol. Soc. London Mem., 21, 307-317.

Michelangeli, D.V., M.Y. AlLen and L. Yuk (1989): El Chichón volcanic aerosols: impact of radiative, thermal, and chemical perturbations, J. Geophys. Res., 94 (D15), 18429-18443.

Minnis, P., E.F. Harrison, L.L. Stowe, G.G. Gibson, F.M. DENN, D.R. Doelling and W.L. SMITH (1993): Radiative climate forcing by the Mt. Pinatubo eruption, Science, 259, 1411-1415.

Moretti, R., P. PAPAle and G. OtTonello (2003): A mod- 
el for the saturation of C-O-H-S fluids in silicate melts, in Volcanic Degassing, edited by C. OPPENHEIMER, D.M. Pyle and J. Barclay, Geol. Soc. London, Spec. Publ. 213, 81-101.

Morton B.R., G. TAYLOR and J.S. TURner (1956): Turbulent gravitational convection from maintained and instantaneous sources, Proc. R. Soc. London Ser. A, 234 (1196), 1-23.

NAVON, O. and V. Lyakhovsky (1998): Vesiculation processes in silicic magmas, in The Physics of Volcanic Eruptions, edited by J.S. GILBERT and R.S.J. SPARKS, Geol. Soc., London, Spec. Publ. 145, 27-50.

NERI, A. and F. Dobran (1994): Influence of eruption parameters on the thermofluid dynamics of collapsing volcanic columns, J. Geophys. Res., 99, 11833-11857.

Neri, A. and G. MACEDONIO (1996): Numerical simulation of collapsing volcanic columns with particles of two sizes, J. Geophys. Res., 101, 8153-8174.

Neri, A., P. PAPAlE and G. MaCEDONIO (1998): The role of magma composition and water content in explosive eruptions, II. Pyroclastic dispersion dynamics, J. Volcanol. Geotherm. Res., 87, 95-115.

Neri, A., A. Di Muro and M. Rosi (2002a): Mass partition during collapsing and transitional columns by using numerical simulations, J. Volcanol. Geotherm. Res., 115, 1-18.

Neri, A., P. Papale, D. Del Seppia and R. Santacroce (2002b): Coupled conduit and atmospheric dispersion dynamics during the Plinian phase of the A.D. 79 Vesuvius eruption, J. Volcanol. Geotherm. Res., 120, 141-160.

Neri, A., G. Macedonio, D. Gidaspow and T. Esposti ONGARO (2003): Multiparticle simulation of collapsing volcanic columns and pyroclastic flows, J. Geophys Res., 108 (B4), 2202.

Newhall C.G. and R.S. PunOngbayan (1996): Fire and mud: Eruptions and Lahars of Mt. Pinatubo, Philippines (Univ Washington Press, Seattle, U.S.A.), 1-1126.

Oberhuber, J.M., M. Herzog, H.-F. Graf and K. Schwanke (1998): Volcanic plume simulation on large scales, $J$. Volcanol. Geotherm. Res., 87, 29-53.

OPPENHEIMER, C. (1998): Volcanological applications of meteorological satellites, Int. J. Remote Sensing, 19, 2829-2864.

Oppenheimer, C., P. Francis and J. Stix (1998): Depletion rates of sulfur dioxide in tropospheric volcanic plumes, Geophys. Res. Lett., 25 (14), 2671-2674.

OpPENHEIMER, C., M. EDMONDS, P. FranCIS and M. Burton (2002): Variation in $\mathrm{HCl} / \mathrm{SO}_{2}$ gas ratios observed by Fourier transform spectroscopy at Soufrière Hills Volcano, Montserrat, in The Eruptions of Soufrière Hills Volcano, Montserrat, from 1995 to 1999, edited by T.H. DruitT and B.P. KokelaAr, Geol. Soc. London Mem., 21, 621-639.

Papale, P. (1998): Volcanic conduit dynamics, in From Magma to Tephra - Modeling Physical Processes of Explosive Volcanic Eruptions, edited by A. FREUNDT and M. Rosi, Developments in Volcanology 4 (Elsevier, Amsterdam), 55-89.

PApale, P. (1999a): Strain-induced magma fragmentation in explosive eruptions, Nature, 397, 425-428.

Papale, P. (1999b): Modeling of the solubility of a twocomponent $\mathrm{H}_{2} \mathrm{O}+\mathrm{CO}_{2}$ fluid in silicate liquids, $A m$. Mineral., 84, 477-492.
PAPAle, P. (2001): Dynamics of magma flow in volcanic conduits with variable fragmentation efficiency and nonequilibrium pumice degassing, J. Geophys. Res., 106, 11043-11065.

Papale, P. and M. Polacci (1999): Role of carbon dioxide in the dynamics of magma ascent in explosive eruptions, Bull. Volcanol., 60, 583-594.

Papale P., A. Neri and G. Macedonio (1998): The role of magma composition and water content in explosive eruptions, I. Magma ascent dynamics, J. Volcanol. Geotherm. Res., 87, 75-93, 1998.

PITARI, G. (1993): A numerical study of the possible perturbation of stratospheric dynamics due to Pinatubo aerosols: Implications for tracer transport, J. Atmos. Sci., 50, 2443-2461.

PITARI, G. and E. MANCINI (2002): Short-term climatic impact of the 1991 volcanic eruption of Mt. Pinatubo and effects on atmospheric tracers, Natural Hazards Earth Sys. Sci., 2, 91-108.

PITARI, G. and V. RizZI (1993): An estimate of the chemical and radiative perturbation of stratospheric ozone following the eruption of Mt. Pinatubo, J. Atmos. Sci., 50, 3260-3276.

Polacci, M., P. PAPAle and M. Rosi (2001): Textural heterogeneities in pumices from the climactic eruption of Mt. Pinatubo, 15 June 1991, and implications for magma ascent dynamics, Bull. Volcanol., 63, 83-97.

PRATHER, M. (1992): Catastrophic loss of stratospheric ozone in dense volcanic clouds, J. Geophys. Res., 97 (D9), 10187-10191, 1992.

Proussevitch, A.A. and D.L. Sahagian (1998): Dynamics and energetics of bubble growth in magmas: analytical formulation and numerical modeling, J. Geophys. Res., 103, 18,223-18,251.

RAmachandran, S., V. RAmaswamy, G.L. STEnchikov and A. Roвоск (2000): Radiative impact of the Mt. Pinatubo volcanic eruption: lower stratospheric response, $J$. Geophys. Res., 105, 24409-24429.

RAmos, J.I. (1995): One-dimensional, time-dependent, homogeneous, two-phase flow in volcanic conduits, Int. J. Num. Methods Fluids, 21, 253-278.

Read, W.G., L. Froidevaux and J.W. Waters (1993): Microwave Limb Sounder measurement of stratospheric $\mathrm{SO}_{2}$ from the Mt. Pinatubo volcano, Geophys. Res. Lett., 20, 1299-1302.

RIEDEL, C., G.G.J. ERNST and M. Riley (2003): Controls on the growth and geometry of pyroclastic constructs, $J$. Volcanol. Geotherm. Res., 127, 121-152.

Ripepe, M., S. Ciliberto and M. Della Schiava (2001): Time constraints for modeling source dynamics of volcanic explosions at Stromboli, J. Geophys. Res., 106 (B5), 8713-8727.

Robertson, A., J. Overpeck, D. Rind, E. Mosley-ThompSon, G. Zielinski, J. LeAN, D. Koch, J. Penner, I. Tegen and R. Healy (2001): Hypothesized climate forcing time series for the last 500 years, J. Geophys. Res., 106, 14783-14803.

Roвock, A. (2000): Volcanic eruptions and climate, Rev. Geophys., 38, 191-219.

Roвock, A. and J. MaO (1992): Winter warming from large volcanic eruptions, Geophys. Res. Lett., 19, 25052408 .

Rose, W.I., D.J. Delene, D.J. Schneider, G.J.S. Bluth, 
A.J. Krueger, I. Sprod, C. McKee, H. Davies and G.G.J. ERNST (1995): Ice in the 1994 Rabaul eruption cloud: implications for volcano hazard and atmospheric effects, Nature, 375, 477-479.

Rose, W.I., G.J.S. BLuTh and G.G.J. ERnst (2000): Integrating retrievals of volcanic cloud characteristics from satellite remote sensors - A summary, Philos. Trans. $R$. Soc., Ser. A, 358, 1585-1606.

Rose, W.I., G.J.S. Bluth, D.J. SchneIDER, G.G.J. ERnst, C.M. Riley and R.G. McGimsey (2001): Observations of 1992 crater peak/spurr volcanic clouds in their first few days of atmospheric residence, J. Geol., 109, 677694.

Rose W.I., Y. Gu, I.M. Watson, T. Yu, G.J.S. Bluth, A.J. Prata, A.J. Krueger, N. Krotokov, S. Carn, M.D. Fromm, D.E. Hunton, A.A. Viggiano, T.M. Miller, J.O. Balletin, G.G.J. ERnst, J.M. ReEves, C. Wilson and B.E. ANDERSON (2003): The February-March 2000 eruption of Hekla, Iceland, from a satellite perspective, in Volcanism and the Earth Atmosphere, edited by A. Robock and C. OpPenheIMER, Am. Geophys. Un., Geophys. Monogr., 139, 107-132..

Rosenfield, J.E., D.B. Considine, P.E., Meade, J.T. BACMEISTER, C.H. JACKMON and M.R. SCHOEBERL (1998): Stratospheric effects of Mt. Pinatubo aerosol studied with a coupled two-dimensional model, J. Geophys. Res., 102, 3649-3670.

Rozanov, E., M. Schlesinger, F. Yang, S. Malyshev, N. Andronova, V. Zubov and T. Egorova (2002): Climate/Chemistry Effects of the Pinatubo volcanic eruption by the UIUC stratosphere/troposphere GCM with interactive photochemistry, J. Geophys. Res., 107, 4594, doi:10.1029/2001JD000974, 2002.

SAar, M.O., M. MANGa and K.V. CASHMAN (2001): Numerical models of the onset of yield strength in crystal-melt suspensions, Earth Planet. Sci. Lett., 187, 367-379.

SASSEN, K. (1992): Evidence for liquid-phase cirrus cloud formation from volcanic aerosol: climate implications, Science, 257, 516-519.

Sassen, K., D.O'C. Starr, G.G. Mace, M.R. Poellot, S.H. Melfi, WL. Eberhard, J.D. SPINHIRNE, E.W. Eloranta, D.E. HAGEN and J. HALlETt (1995): The 5-6 December 1991 FIRE IFO II jet stream cirrus case study: possible influences on volcanic aerosols, J. Atmos. Sci., 52, 97123.

Sato, M., J.E. Hansen, M.P. McCormick and J.B. PolLACK (1993): Stratospheric aerosol optical depths 1850-1990, J. Geophys. Res., 98, 22,987-22,994.

Shindell, D.T., G.A. Schmidt, R.L. Miller and D. Rind (2003): Volcanic and solar forcing of climate change during the Preindustrial Era, J. Climatol., 16, 40944107, doi: 10.1175/1520-0442.

Simpson, J.J.S., G.L.H. Hufford, D. Pierz, R. ServranckX, J.S. Berg and C. BAuER (2002): The February 2001 eruption of Mt. Cleveland, Alaska: case study of an aviation hazard, Weather Forecasting, 17, 691-704.

Solomon, S., R.W. Portmann, R.R. Garcia, L.W. ThomaSON, L.R. PoOlE and M.P. MCCORMICK (1996): The role of aerosol variations in anthropogenic ozone depletion at northern midlatitudes, J. Geophys. Res., 101, 6713-6727.

Soo, S.L. (1967): Fluid Dynamics of Multiphase Systems (Blaisdell-Ginn, Waltham, MA).
SPARKS, R.S.J. and L. WILSON (1982): Explosive volcanic eruptions, IV. Observations of plume dynamics during the 1979 Soufrière eruption, St. Vincent, Geophys. J.R. Astron. Soc., 69, 551-570.

SpARKS, R.S.J., M.I. BuRsiK, G.J. Ablay, R.M.I. ThOMAs and S.N. CAREY (1992): Sedimentation of tephra by volcanic plumes, Part 2. Controls on thickness and grainsize variations of tephra fall deposits, Bull Volcanol., 54, 685-695.

SPARKS R.S.J., M.I. Bursik, S.N. CAREY, J.S. GILbERT, L.S. Glaze, H. Siggurdsson and A.W. Woods (1997): Volcanic Plumes (John Wiley and Sons, New York), pp. 574.

Spieler, O., M. Alidibirov and D.B. Dingwell (2003): Grain-size characteristics of experimental pyroclasts of 1980 Mt. St. Helens cryptodome dacite: effects of pressure drop and temperature, Bull. Volcanol., 65, 90-104.

StenChIKOV, G.L., I. KIRCHNER, A. RobOCK, H.-F. GRAF, J. C. Antuña, R. G. Grainger, A. LAmbert and L. ThOMASON (1998): Radiative forcing from the $1991 \mathrm{Mt}$. Pinatubo volcanic eruption, J. Geophys. Res., 103, 13,83713,857 .

Stenchikov, G., A. Robock, V. Rmaswamy, M. D SCHWARZKOPF, K. HAMILTON and S. RAMACHANDRAN (2002): Arctic oscillation response to the 1991 Mt. Pinatubo eruption: effects of volcanic aerosols and ozone depletion, J. Geophys. Res., 107, 4803, doi: 10.1029/ /2002JD002090, 2002.

Stevenson, D.S., C.E. Johnson, E.J. Highwood, V. Gauci, W.J. Collins and R.G. DeRwENT (2003): Atmospheric impact of the 1783-1784 Laki eruption, Part I. Chemistry modeling, Atmos. Chem. Phys., 3, 487-507.

SuZuki, Y.J., T. Koyaguchi, M. OgaWA and I. Hachisu (2005): A numerical study of turbulent mixing in eruption clouds using a three-dimensional fluid dynamics model, J. Geophys. Res., 110 (B8), B08201, doi: 10.1029/2004JB003460

TABAzAdeH, A. and R.P. TuRCo (1993): Stratospheric chlorine injection by volcanic eruptions: $\mathrm{HCl}$ scavenging and implications for ozone, Science, 260, 1082-1086.

Tait, S., C. Jaupart and S. Vergniolle (1989): Pressure, gas content and eruption periodicity of a shallow, crystallising magma chamber, Earth Planet. Sci. Lett., 92 , 107-123.

Textor, C. and G.G.J. ERnst (2004): Comment on «Particle aggregation in volcanic eruption columns» by Graham Veitch and Andrew W. Woods, J. Geophys. Res., 106 (B11), 26.425-26.441.

Textor, C., H.-F. Graf, C. Timmreck and A. Robock (2003a): Emissions from volcanoes, in Emissions of Chemical Compounds and Aerosols in the Atmosphere, edited by C. Granier, C. Reeves and P. Artaxo (Kluwer, Dordrecht), 269-303.

Textor, C., P.M. Sachs, H.-F. Graf and T. Hansteen (2003b): The 12900 years BP Laacher See eruption: estimation of volatile yields and simulation of their fate in the plume, in Volcanic Degassing, edited by C. OpPENheimer, D. Pyle and J. Barclay, Geol. Soc. Spec. Publ. 213.

Textor, C., M. Herzog, H.-F. Graf and J.M. Oberhuber (2003c): Injection of gases into the stratosphere by explosive volcanic eruptions, J. Geophys. Res., 108 (D19), 4606, doi: 10.1029/2002JD002987. 
Textor, C., H.-F. Graf, M. Herzog, J.M. Oberhuber, W.I. Rose and G.G.J. ERNST (2005a): Ash aggregation in volcanic eruption columns, Part I. Hydrometeor-ash particle growth in volcanic eruption column, J. Volcanol. Geotherm. Res. (in press).

Textor, C., H.-F. Graf, M. Herzog, J.M. Oberhuber, W.I. Rose and G.G.J. ERNST (2005b): Ash aggregation in volcanic eruption columns, Part II. Numerical experiments, J. Volcanol. Geotherm. Res. (in press).

Tie, X., G.P. Brasseur, B. Briegleb and C. Granier (1994a): Two-dimensional coupled dynamical/chemical/microphysical simulation of global distribution of El Chichón volcanic aerosols, J. Geophys. Res., 99, 16,779-16,792.

Tie, X., G.P. Brasseur, B. Briegleb and C. Granier (1994b): Two-dimensional simulation of Pinatubo aerosol and its effect on stratospheric ozone, J. Geophys. Res., 99, 20,545-20,562.

Timmreck, C., H.-F. Graf and I. Kirchner (1999): A one and a half year interactive simulation of Mt. Pinatubo aerosol, J. Geophys. Res., 104, 9337-9360.

Timmreck, C., H.-F. GraF and B. STEIL (2003): Aerosol chemistry interactions after the Mt. Pinatubo eruption, in Volcanism and the Earth's Atmosphere, edited by A. Robock and C. OpPenheIMER, Am. Geophys. Un. Monogr., 139, 213-225.

Todesco, M., A. Neri, T. Esposti Ongaro, P. Papale., G. Macedonio, R. Santacroce and A. Longo (2002): Pyroclastic flow hazard assessment at Vesuvius by using numerical modeling, 1. Large scale dynamics, Bull. Volcanol., 64, 155-177.

Trentmann, J., M.O. Andreae, H.-F. Graf, P.V. Hobbs, R.D. Ottmar and T. Trautmann (2002): Simulation of a biomass-burning plume: comparison of model results with observations, J. Geophys. Res., 107 (D2), 4013, doi:10.1029/2001JD000410.

Tupper, A., K. Kinoshita,C. Kanagaki, N. Iino and Y. KaMADA (2003): Observations of volcanic cloud heights and ash-atmosphere interactions, in WMO/ICAO Third International Workshop on Volcanic Ash, September 29-October 3, 2003, Toulouse, France.

Turcotte, D.L., H. Ockendon, J.R. OCKEndon and S.J. Cowley (1990): A mathematical model of vulcanian eruptions, Geophys. J. Int., 103, 211-217.

TwomeY, S. (1974): Pollution and planetary albedo, Atmos. Environ., 8, 1251-1265.

VAlentine, G.A. and K.H. Wohletz (1989): Numerical Models of Plinian eruption columns and pyroclastic flows, J. Geophys Res., 94, 1867-1887.

VAlentine, G.A., K.H. WOHLETZ and S.W. KiefFER (1992): Effects of topography of facies and compositional zonation in caldera-related ignimbrites, Geol. Soc. Am. Bull., 104, 154-165.

VeItch, G. and A.W. Woods (2000): Particle recycling and oscillations of volcanic eruption columns, J. Geophys. Res., 105 (B2), 2829-2842.

Veitch, G. and A.W. Woods (2001): Particle aggregation in volcanic eruption columns, J. Geophys. Res., 106 (B11), 26425-26441.

Veitch, G. and A.W. Woods (2002): Particle recycling in volcanic plumes, Bull. Volcanol., 64 (1), 31-39.

VeITCH, G. and A.W. Woods (2004): Reply to comment by C. Textor and G.G.J. Ernst on «Particle aggregation in volcanic eruption columns», J. Geophys. Res., 109 (B5), B05203, 10.1029/2003JB002388.

Vergniolle, S. and G. Brandeis (1994): Origin of the sound generated by Strombolian explosions, Geophys. Res. Lett., 21 (18), 1959-1962.

Weisenstein, D.K., G.K. Yue, M.K. W. Ko, N.-D. Sze, J.M. RodrigueZ and C.J. SCOTT (1997): A two-dimensional model of sulfur species and aerosols, J. Geophys. Res., 102, 13019-13053.

WiLson, L. (1972): Explosive volcanic eruptions, II. The atmospheric trajectories of pyroclasts, Geophys. J. R. Astron. Soc., 30, 381-392.

Wilson, L. (1976): Explosive volcanic eruptions, III. Plinian eruption columns, Geophys. J. R. Astron. Soc., 45, 543-556.

WiLSON, L. and G.P.L. WALKER (1987): Explosive volcanic eruptions, VIII. Ejecta dispersal in Plinian columns: The control of eruption conditions and atmospheric properties, Geophys. J. R. Astron. Soc., 89, 657-679.

WiLson, L., R.S.J. SPARKS and G.P.L. WALKER (1980): Explosive volcanic eruptions, IV. The control of magma properties and conduit geometry on eruption column behavior, Geophys. J. R. Astron. Soc., 63, 117-148.

WMO (World Meteorological Organization) (2003): Scientific assessment of ozone depletion: 2002, Global Ozone Research and Monitoring Project, Rep. No. 47, pp. 498.

Wohletz, K.H., T.R. McGetchin, M.T. SANDFORD II and E.M. Jones (1984): Hydrodynamic aspects of calderaforming eruptions: numerical models, J. Geophys Res., 89, 8269-8285.

Woods, A.W. (1988): The dynamics and thermodynamics of eruption columns, Bull. Volcanol., 50 (3), 169-193.

Woods, A.W. (1993): Moist convection and the injection of volcanic ash into the atmosphere, J. Geophys. Res., 98, 17627-17636.

Woods, A.W. (1998): Observation and models of volcanic eruption column, in The Physics of Explosive Volcanic Eruptions, edited by J.S. GILBERT and R.S.J. SPARKS, Geol. Soc. London, Spec. Publ., 145, 91-114.

Young, R.E., H. HoubeN and O.B. Toon (1994): Radiatively forced dispersion of the Mt. Pinatubo volcanic cloud and induced temperature perturbations in the stratosphere during the first few months following the eruption, Geophys. Res. Lett., 21, 369-372. 